\title{
Social Capital and Debt Contracting: Evidence from Bank Loans and Public Bonds
}

\author{
Iftekhar Hasan, Chun Keung Hoi, Qiang Wu, and Hao Zhang*
}

\begin{abstract}
We find that firms headquartered in U.S. counties with higher levels of social capital incur lower bank loan spreads. This finding is robust to using organ donation as an alternative social capital measure and incremental to the effects of religiosity, corporate social responsibility, and tax avoidance. We identify the causal relation using companies with a social-capital-changing headquarters relocation. We also find that high-social-capital firms face loosened nonprice loan terms, incur lower at-issue bond spreads, and prefer public bonds over bank loans. We conclude that debt holders perceive social capital as providing environmental pressure that constrains opportunistic firm behaviors in debt contracting.
\end{abstract}

\section{Introduction}

Social capital is an important construct that has been studied extensively in the social sciences (Coleman (1988), Putnam (1993)) and shown to have positive economic benefits for societies, communities, organizations, and individuals (Fukuyama (1995), Knack and Keefer (1997), Putnam (2001), and Buonanno, Montolio, and Vanin (2009)). However, we still know little about how social capital affects publicly listed corporations. In this study, we explore the economic benefits of social capital for corporations by examining its effects on debt contracting, with a special focus on the cost of bank loans.

Guiso, Sapienza, and Zingales (2010) argue that economic research would benefit by defining social capital as the confluence of effects arising from social networks and shared common beliefs that help cooperation, hereafter "cooperative norms." We use that definition of social capital in this study. Specifically, we examine whether social capital at the county level in the United States, as captured by the strength of cooperative norms and the density of social networks in the

*Hasan, ihasan@fordham.edu, Fordham University, Bank of Finland, and University of Sydney; Hoi, ckhoi@saunders.rit.edu; Zhang (corresponding author), hzhang@ saunders.rit.edu, Saunders College of Business, Rochester Institute of Technology (RIT); and Wu, wuq2@rpi.edu, Lally School of Management, Rensselaer Polytechnic Institute (RPI). The paper benefited greatly from valuable comments and suggestions from an anonymous referee and Paul Malatesta (the editor). We are grateful for helpful comments from colleagues at our respective institutions. Hoi and Zhang thank the Saunders College of Business at RIT for summer research support. Wu thanks the Lally School of Management at RPI for research support through an A. C. Lawrence Research Fellowship. 
county, affects the cost of bank loans obtained by corporations headquartered in the county. ${ }^{1}$

Cooperative norms are nonreligious social norms that constrain narrow selfinterest (Knack and Keefer (1997)), limit opportunistic behaviors in transactions (Coleman (1988)), and help overcome the free-rider problem (Guiso et al. (2010)). In communities with strong cooperative norms, individuals should view opportunistic behaviors as contradictory to the prescribed values associated with the attendant norms, resulting in both internal and external sanctions that constrain such behaviors (Coleman (1988), Elster (1989)). Moreover, communities with dense social networks have more effective communications and enforcement of the attendant norms in the community (Coleman (1988), Spagnolo (1999)). Therefore, one would expect strong cooperative norms and dense social networks in a county to foster an environment that limits opportunistic behaviors. It follows that debt holders, including banks and bond investors, could perceive social capital as constraining opportunistic firm behaviors in debt contracting. Consequently, we predict that firms headquartered in counties with higher levels of social capital incur lower loan spreads and less stringent nonprice loan terms when obtaining bank loans, face lower at-issue yield spreads when issuing public bonds, and prefer bonds over loans when seeking debt financing. ${ }^{2}$

We use the data from the Northeast Regional Center for Rural Development (NRCRD) at Pennsylvania State University to measure the levels of social capital across U.S. counties. We measure direct bank loan cost using loan spread, which is defined as the basis points (bps) a borrower pays in excess of the London Interbank Offered Rate (LIBOR) or LIBOR equivalent for each dollar drawn down. Using a comprehensive sample of around 32,000 bank loan facilities issued to U.S. public firms during the period 1990-2012, we find a negative and statistically significant relation between county-level social capital and loan spread after controlling for firm characteristics, loan attributes, county-level demographic factors, state, year, and industry fixed effects. Our results are economically meaningful. Specifically, when the level of social capital increases by 1 standard deviation in the data, our coefficient estimates translate into a decrease of 4.33 bps in loan spread, on average, implying a reduction in total interest expenses of roughly $\$ 0.528$ million.

The finding is robust in a battery of sensitivity tests. We find that social capital reduces bank loan cost when we use organ donation as an alternative social

\footnotetext{
${ }^{1}$ We choose to examine the effect of social capital in the U.S. setting for two reasons. First, recent studies in accounting and finance find that local religious norms and networks across counties and metropolitan areas in the United States reduce the cost of debt (Cai and Shi (2014), Jiang, John, Li, and Qian (2014)). So, it is natural to query whether nonreligious cooperative social norms and social networks also reduce the cost of debt. Second, we wish to provide results using large-scale data, and it is only in the U.S. setting that we are able to obtain the requisite data on cooperative norms and social networks through the NRCRD at Pennsylvania State University. Our empirical strategy is similar to that used by Guiso, Sapienza, and Zingales (2004). These authors examine the effect of cross-province variations in social capital in Italy. An additional advantage is that the strategy isolates the effects of cross-nation differences in monetary policy and inflation, which could have significant effects on the cost of debt capital across nations.

${ }^{2}$ Although we argue that the primary effect of social capital is that it constrains opportunistic firm behaviors in debt contracting, we realize that social capital could have a concomitant secondary effect on bank loan contracting. Section II.B discusses both of these effects.
} 
capital measure; after we control for the effects arising from local religiosity (Cai and Shi (2014), Jiang et al. (2014)), corporate social responsibility (Goss and Roberts (2011)), and corporate tax avoidance (Hasan, Hoi, Wu, and Zhang (2014)); and when we use an instrumental-variable 2-stage regression analysis to address the endogeneity of social capital due to omitted variables that are potentially correlated with social capital and bank loan cost.

We identify the causal effect of social capital on loan spread using a quasiexperiment that exploits corporate headquarters relocation events resulting in either an increase or a decrease in social capital. Using a difference-in-differences analysis, we compare the over-time changes in loan spreads across firms that relocated to a county with a higher level of social capital against firms that relocated to a county with a lower level of social capital. We find that firms with a social-capital-increasing relocation experience significantly larger reductions in overtime changes in the cost of bank loans they obtain between the pre- and postrelocation periods when compared with firms with a social-capital-decreasing relocation.

With respect to nonprice loan terms, we find that banks are less likely to impose a collateral requirement in loans issued to firms headquartered in U.S. counties with higher levels of social capital. Additionally, social capital reduces the likelihood that at least one covenant requirement is used, and it reduces the total number of covenants used in a loan facility.

We use a comprehensive sample of bond-issuing firms during the same sample period 1990-2012 to explore the relation between social capital and the cost of public bonds. The findings indicate that firms located in U.S. counties with higher levels of social capital incur lower at-issue yield spreads when issuing public bonds. Moreover, we find that firms headquartered in counties with higher levels of social capital prefer public bonds over private bank loans when seeking debt financing. Because the personal relationships between bond investors and managers of borrowing firms are very likely infrequent, these results show that the documented negative relations between social capital and the cost of debt are unlikely to be driven by personal relationships and social networks between debt holders and borrowers (Engelberg, Gao, and Parsons (2012)).

Taken together, the findings on loan and bond contracting lend credence to the argument that banks and bond investors, that is, both private and public lenders, perceive social capital as providing environmental pressure that mitigates the specter of risks in terms of opportunistic firm behaviors they face in debt contracting, and, consequently, banks and bond investors offer more favorable debt contract terms when lending to firms headquartered in counties with higher levels of social capital.

These findings enhance the understanding of the influences of social environment vis-à-vis social capital on debt contracting. They bring together the two disparate streams of literature on social capital and debt contracting. To the best of our knowledge, this is the first study to introduce the social capital construct into the debt-contracting literature. Given that few studies have examined the influences of social environment on debt contracting, these findings provide an important, novel contribution to the debt-contracting literature. The results show that both private and public lenders, that is, both banks and bond investors, perceive 
social capital as cultivating an environment that mitigates the specter of the opportunistic firm behaviors they face.

Guiso et al. (2010) argue that social capital vis-à-vis strong cooperative norms and dense social networks has positive economic payoffs. Our findings provide strong support for this argument. Although prior studies have used said definition to explore the beneficial effects of social capital on a range of social and economic phenomena (Knack and Keefer (1997), Guiso et al. (2004), and Buonanno et al. (2009)), few studies, except those of Jha and Chen (2015), Hasan, Hoi, $\mathrm{Wu}$, and Zhang (2017), and Hoi, Wu, and Zhang (2017), have examined the effect of social capital on corporations, and none has examined the effects of social capital on debt contracting, either in the private bank debt or public bond market. In this context, our study makes a novel contribution to the literature. It shows that social capital engenders potentially significant positive economic payoffs for firms because it reduces the cost of debt capital they incur.

The remainder of the paper proceeds as follows: In the next section, we build on the literature to develop our hypotheses. Section III introduces the variable definitions, describes the baseline regression model, discusses sample construction, and presents descriptive statistics. Section IV discusses regression results based on bank loan spreads. Section V describes identification strategies based on a difference-in-differences test and instrumental-variable 2-stage regression models. Section VI discusses regression results based on nonprice loan terms, public bond yields, and choice of debt financing. We conclude in Section VII.

\section{Hypotheses Development}

Decision makers can use their private information to exploit debt holders, resulting in classic contractual problems such as adverse selection and moral hazard. In this study, we focus on the extent to which social capital limits moral hazard in debt contracting. In this section, we develop four hypotheses expounding the effects of social capital on bank loan spreads, nonprice loan terms, public bond yields, and firm debt-financing choice between bank loans and public bonds.

\section{A. Social Capital and Moral Hazard in Debt Contracting}

We define moral hazard as opportunistic and self-serving corporate dealings that have the potential to benefit shareholders of the firm at the expense of debt holders. These dealings include overinvestment (Galai and Masulis (1976)), claim dilution (Bebchuk (2002)), and accounting manipulation to avoid covenant violations (DeFond and Jiambalvo (1994)). Because the dealings are made by individuals, one must trace the incidence of moral hazard back to the individual decision makers. Accordingly, we conjecture that social capital affects debt contracting by changing decision makers' perceived costs and benefits associated with perpetrating opportunistic behaviors against debt holders.

Following Coleman (1988), Knack and Keefer (1997), and Guiso et al. (2010), we define social capital as an environmental construct that captures the confluence of effects arising from the strength of cooperative norms and the density of associational networks. There is considerable evidence that individuals in communities with higher levels of social capital (i.e., strong cooperative norms 
and dense social networks) are less likely to engage in opportunistic, self-serving behaviors. ${ }^{3}$ This is because opportunistic behaviors are contradictory to the prescribed values associated with cooperative norms, while dense social networks intensify the external social sanctions (Coleman (1988)) such as social ostracism (Uhlaner (1989)) and stigmatization (Posner (2000)), and heighten negative moral sentiments such as guilt and shame associated with perpetrating opportunistic behaviors. Further, in communities with higher levels of social capital, perpetrators of opportunistic behaviors could suffer significant innate discomfort even if the actual behaviors are unobserved (Elster (1989)). This is because individuals have a great need to maintain a moral self-concept (Mazar, Amir, and Ariely (2008), Monin and Jordan (2009)), and opportunistic behaviors highlight the discrepancies between one's moral self-concept and actual behaviors (Higgins (1987)).

Accordingly, we conjecture that social capital affects debt contracting by increasing decision makers' perceived marginal costs of perpetrating opportunistic firm behaviors against debt holders, which, in turn, incentivizes the decision makers to behave in a cooperative way that reduces the specter of the moral hazards facing debt holders, particularly those moral hazards that debt holders face in the postcontract period.

\section{B. The Effects of Social Capital on Bank Loan Spreads}

There is substantial evidence that banks demand higher loan spreads in anticipation of the potential risks they face in debt contracting (Bharath, Sunder, and Sunder (2008), Graham, Li, and Qiu (2008), and Hasan et al. (2014)). Accordingly, if banks perceive social capital as providing environmental pressure that constrains moral hazards in debt contracting, we expect that banks demand lower loan spreads when lending to firms located in communities with higher levels of social capital.

Additionally, because cooperation begets trustworthiness and trustworthiness begets trust, banks could perceive firms as more trustworthy and place greater trust in those firms located in communities with higher levels of social capital (Fukuyama (1997), Guiso et al. (2004)). In this way, social capital can generate a concomitant secondary virtuous effect in that banks demand lower loan spreads when lending to firms located in higher-social-capital communities.

The two aforementioned effects lead to the same prediction for bank loan spreads. Because our focus is to provide robust evidence to establish a causal relation between social capital and the cost of bank loans, we do not attempt to unpack these effects. Instead, we focus on the following refutable hypothesis:

${ }^{3}$ For example, Uzzi (1996), Fukuyama (1997), and Fischer and Pollock (2004) argue that when people depend on each other in a dense social network, the repeated games over time cultivate a code of conduct that deters opportunistic behavior and encourages the propensity to honor obligations. Posner (1980) finds that dense social networks in African villages reduce the opportunistic behaviors of villagers. La Porta, Lopez-de-Silanes, Shleifer, and Vishny (1997) and Bjornskov (2003) find that individuals in higher-social-capital countries are less likely to accept a bribe or bribe others. Lederman, Loayza, and Menendez (2002) and Buonanno et al. (2009) find that social capital is negatively associated with criminal behaviors. 
Hypothesis 1. Firms located in areas with strong cooperative norms and dense social networks incur lower loan spreads when obtaining bank loans.

\section{The Effect of Social Capital on Nonprice Loan Terms}

There is evidence that banks also use nonprice contractual terms to mitigate the risks they face. Strahan (1999) finds that banks use both loan spreads and nonprice loan terms to mitigate borrower risk. Bharath et al. ((2008), p. 6) argue that because "banks have superior information from the borrower and make investments in monitoring the borrowers, they do not face the same degree of renegotiation costs as dispersed public bondholders"; consequently, banks have significantly greater incentives to use "detailed and tailor-made contracts, breaches of which trigger renegotiation." Indeed, they provide robust empirical findings that banks adjust both loan spreads and nonprice loan terms to mitigate the risks they face, whereas bond investors adjust at-issue yield spreads only. Additionally, Graham et al. (2008) and Hasan et al. (2014) find corroborating evidence banks to impose more stringent collateral and covenant requirements when lending to firms with greater risks.

Accordingly, if banks perceive social capital as constraining moral hazards in debt contracting, or banks perceive firms located in communities with higher levels of social capital as more trustworthy and thus place greater trust in these firms, one would expect banks to impose less stringent nonprice loan terms when lending to firms located in communities with higher levels of social capital. This argument leads to the following refutable hypothesis:

Hypothesis 2. Firms located in areas with strong cooperative norms and dense social networks incur less stringent nonprice terms when obtaining bank loans.

\section{The Effect of Social Capital on At-Issue Bond Spreads}

There is substantial evidence that bond investors use bond yield spreads to mitigate borrower risks (e.g., Klock, Mansi, and Maxwell (2005), Bharath et al. (2008), and Hasan et al. (2014)). In particular, Bharath et al. (2008) find that bond investors are more sensitive than banks in pricing borrower risks into interest spreads, because bond investors have reduced flexibility in contract renegotiation after bond issuance. Accordingly, if bond investors perceive social capital as constraining moral hazards in debt contracting or if they place greater trust in high-social-capital firms, one would expect that they demand lower interest spreads when lending to firms located in communities with higher levels of social capital. This argument leads to the following refutable hypothesis:

Hypothesis 3. Firms located in areas with strong cooperative norms and dense social networks incur lower at-issue bond spreads when issuing public bonds.

\section{E. The Effects of Social Capital on Debt-Financing Choice}

Theoretical models, such as those advanced by Diamond (1991) and Besanko and Kanatas (1993), indicate that loans are more efficient than bonds in resolving moral hazards in debt contracting. This is because dispersed public bond investors face a significant free-rider problem in monitoring; however, because banks do not suffer this free-rider problem, they have stronger incentives to gather information and monitor the borrower behaviors. Accordingly, Denis and Mihov (2003) 
argue that firms with greater risks stemming from informational, agency, and other contractual problems prefer bank loans over public bonds when seeking debt financing. ${ }^{4}$

However, the aforementioned preference for bank loans could be dampened by the presence of a social environment that limits opportunistic behaviors. Guiso et al. (2004), (2010) find that social capital helps cultivate such a social environment; they show that social capital helps overcome contractual problems, because it encourages cooperation and mitigates opportunistic behaviors in transactions. Accordingly, if social capital constrains opportunistic firm behaviors in debt contracting, a higher level of social capital could be associated with a reduced preference for bank loans over public bonds when firms are seeking debt financing. This argument leads to the following refutable hypothesis:

Hypothesis 4. Firms located in areas with strong cooperative norms and dense social networks are less likely to use bank loans relative to public bonds when seeking debt financing.

\section{Research Design, Sample Selection, and Summary Statistics}

This section introduces variable definitions, presents the baseline regression model and the sample selection procedure, and discusses the descriptive statistics.

\section{A. Measures of Social Capital}

We use data from the NRCRD at Pennsylvania State University to estimate the levels of social capital in U.S. counties in the years 1990, 1997, 2005, and 2009. Specifically, we use two NRCRD variables to capture the strength of county-level cooperative norms. PVOTE is the percentage of eligible voters who voted in presidential elections (Alesina and La Ferrara (2000)). RESPN is the county-level response rate to the Census Bureau's decennial census (Knack (2002)). Guiso et al. (2004), (2010), Funk (2010), and Knack (2002) argue that because there are no legal or economic incentives to vote or to take census surveys, data on voter turnout and census response rate are more likely to capture the ramifications of social norms that emphasize cooperative behaviors.

Coleman (1988) and Putnam (1993) argue that dense social networks, particularly those involving face-to-face, horizontal social interactions and relations among individuals, are more likely to promote cooperation and reinforce the attendant norms of the networks. We use two NRCRD variables to capture the density of social networks in a county. ASSN is the number of social organizations in the county divided by populations per 100,000 , where social organizations include religious organizations, civic associations, business associations, political organizations, labor organizations, bowling centers, physical fitness facilities, public golf courses, and sports clubs. NCCS is the total number of tax-exempt nonprofit

\footnotetext{
${ }^{4}$ Consistent with this argument, prior studies observe a preference for bank loans among small firms (Fama (1985), Nakamura (1993)), firms with greater return volatility (Krishnaswami, Spindt, and Subramaniam (1999)), firms with greater research and development (R\&D) outlay (Denis and Mihov (2003)), and firms with lower accounting quality (Bharath et al. (2008)).
} 
organizations with a domestic focus in the county divided by populations per 10,000. The Appendix presents detailed definitions and additional information for all NRCRD variables.

Following Rupasingha, Goetz, and Freshwater (2006), we use a principal component analysis (PCA) to construct our own measure of county-level social capital in the United States. SOCIAL_CAPITAL is the first principal component from a PCA based on PVOTE, RESPN, NCCS, and ASSN.

Our measure of SOCIAL_CAPITAL is highly correlated with the social capital indices reported in the NRCRD data set. However, it is not identical to the social capital indices provided by the NRCRD. This is because we adjust the NCCS and ASSN data in 1990 and 1997. First, we use only the 10 types of social organizations that are consistently reported by the NRCRD to account for social organizations. This affects the ASSN data in both 1990 and 1997. Second, we find that the NRCRD underreports the number of nonprofit organizations in 1990; consequently, we use a time trend method to adjust the NCCS data in $1990 .^{5}$ The Appendix explains these procedures.

Figure 1 presents the spatial distribution of SOCIAL_CAPITAL in 2005. We rank the variable and use the corresponding quintile rank to create this snapshot. A darker shade represents a higher rank of the variable. This snapshot shows that social capital is higher in upper Midwest/Northwest counties and lower in Southeast/Southwest counties. The spatial distribution of social capital is similar to that reported by Rupasingha et al. (2006), who use the 1997 data from the NRCRD.

\section{B. Regression Models}

We use the following regression model, hereafter "baseline model," to test Hypothesis 1:

$\begin{aligned} \ln \left(\operatorname{SPREAD}_{t}\right)= & f\left(\text { SOCIAL_CAPITAL }_{t-1}, \text { FIRM_ATTRIBUTES }_{t-1},\right. \\ & \text { LOAN_CHARACTERISTICS }_{t}, \\ & \text { COUNTY_ATTRIBUTES } \\ & \\ & \text { STATE_FIXED_EFFECTS }, \\ & \text { YEAR_FIXED_EFFECTS, } \\ & \text { INDUSTRY_FIXED_EFFECTS }),\end{aligned}$

where $\ln \left(\mathrm{SPREAD}_{t}\right)$ is the natural logarithm of the amount of loan interest payment in bps over LIBOR or LIBOR equivalent for each dollar drawn down (i.e., the all-in loan spread drawn) for a loan facility a firm obtains in year $t$, and SOCIAL_CAPITAL ${ }_{t-1}$ is the level of social capital in the county of the firm's headquarters location in year $t-1$, where $t-1$ denotes the year

${ }^{5}$ The NRCRD reports the variables and data in two different data sets. The old data set, OLD_NRCRD, reports data for 1990, 1997, and 2005. The new data set, NEW_NRCRD, reports data for 1997, 2005, and 2009. There are discrepancies in the NCCS and ASSN variables between OLD_NRCRD and NEW_NRCRD. We make adjustments to these two variables for the years 1990 and 1997. In the end, our social-capital measures in 1990 and 1997 are highly correlated with the corresponding social-capital indexes reported by the NRCRD. The corresponding Pearson correlation coefficients are statistically significant at the $1 \%$ level, and they are 0.93 and 0.99 , respectively. Given the high correlation, it is not surprising that our main findings are qualitatively unchanged when we use the original NRCRD social-capital indexes as an alternate measure of social capital. 
FIGURE 1

\section{Spatial Distribution of Social Capital Measure}

Figure 1 presents the spatial distribution for the quintile rank of SOCIAL_CAPITAL in the contiguous United States. For brevity, we depict only the variable based on social capital data in 2005. The counties with social capital measures in a higher quintile are displayed with a darker shade, whereas the counties with social capital measures in a lower quintile are displayed with a lighter shade.

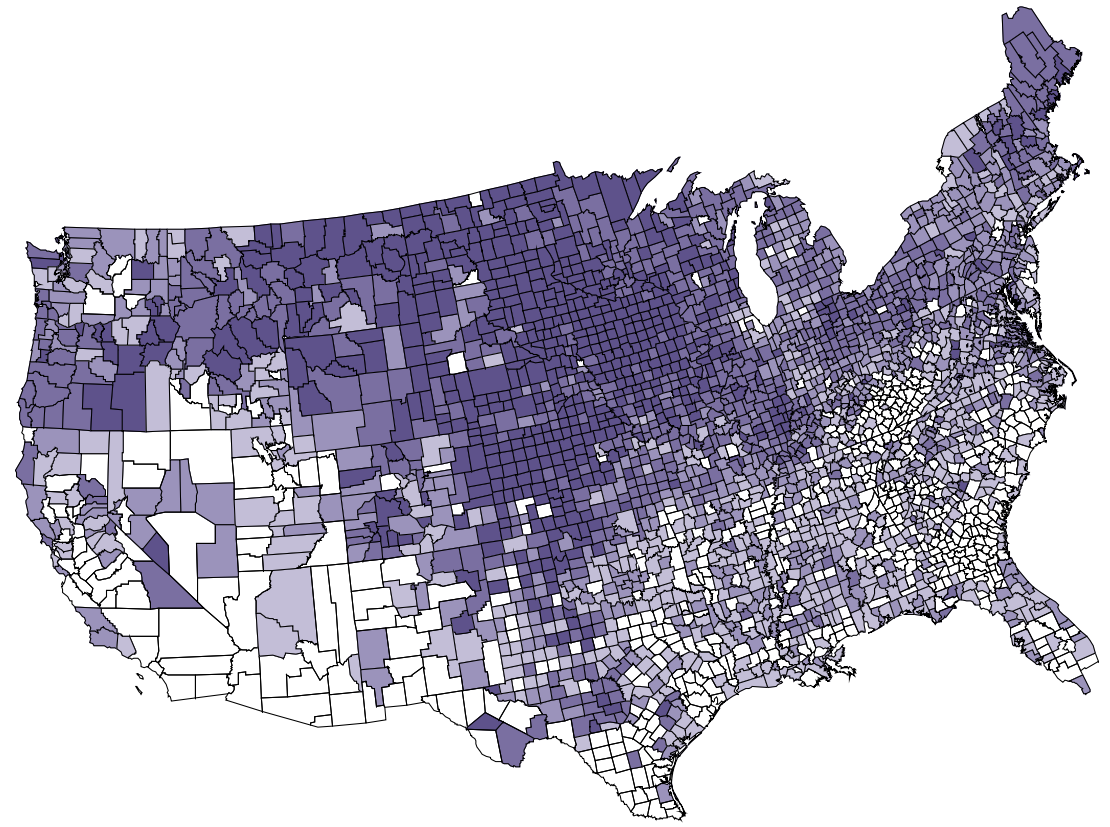

immediately prior to the year in which the firm obtains a loan facility. Following Graham et al. (2008), we include firm-level variables in year $t-1$ (FIRM_ATTRIBUTES ${ }_{t-1}$ ) to control for the effects of firm size, profitability, growth potential $\left(\mathrm{MB}_{t-1}\right)$, leverage, asset structure (TANGIBILITY $\left.{ }_{t-1}\right)$, default probability $\left(\mathrm{ZSCORE}_{t-1}\right)$, cash holding, earnings volatility, and sales growth. We include contemporaneous loan-level variables (LOAN_CHARACTERISTICS ${ }_{t}$ ) to control for the effects of loan size, loan maturity, loan syndication, debt rating, loan types, and loan purposes. We also include county-level variables in year $t-1$ $\left(\right.$ COUNTY_ATTRIBUTES $\left._{t-1}\right)$ to isolate potential effects arising from county demographic factors such as income level, population size, education level, and age profile of county residents (Rupasingha and Goetz (2007)). We have no a priori reason to expect that these county-level demographic variables are systematically correlated with bank loan cost. So, the idea here is to ensure that the effect of social capital is not confounded by these factors. State laws are different in terms of establishing property rights during a bankruptcy procedure. It is possible that these state-level differences could affect debt contracting. We address this concern by including state fixed effects to control for the differences at the state level. Finally, we control for year fixed effects and 2-digit Standard Industrial Classification (SIC) industry fixed effects. Table 1 presents detailed definitions of all variables used in the regressions. For brevity, hereafter, we drop the year subscripts for all ensuing discussions. 


\section{TABLE 1 \\ Variable Definitions}

Table 1 presents definitions of the variables in the baseline regression model. Loan data are from the Thomson Reuters LPC DealScan database. Social capital data are from the NRCRD at Pennsylvania State University. Firm data are from the S\&P Compustat database. Data for county demographic factors are from the Bureau of Economic Analysis.

Variables

Definitions

Panel A. Loan Attributes (based on loan-year-level data for a loan obtained by a firm in year $t$ )

SPREAD $t$

Loan spread is measured as all-in loan spread drawn in the DealScan database for a given loan facility a firm obtains in year $t$. All-in loan spread drawn is defined as the amount the borrower pays in bps over LIBOR or LIBOR equivalent for each dollar drawn down.

$\ln \left(\mathrm{SPREAD}_{t}\right)$

Natural logarithm of SPREAD .

LOAN_SIZE ${ }_{t}$

Total amount of a loan facility (in \$millions) obtained by a firm in year $t$.

In(LOAN_SIZE $)_{t}$

Natural logarithm of LOAN_SIZE . $_{\text {. }}$

MATURITY $_{t}$

Number of months to maturity of a loan facility obtained by a firm in year $t$.

DUMMY_SYNDICATION Equals 1 if the loan obtained by a firm in year $t$ is syndicated, and 0 otherwise.

DEBT_RATING

A categorical variable capturing S\&P senior debt rating for a firm in year $t$. This variable equals 1 if the debt rating is $A A A, 2$ if the debt rating is $A A, 3$ if the debt rating is $A$, etc.

DUMMY_COLLATERAL $t$

Equals 1 if a loan obtained by a firm in year $t$ contains a collateral requirement, and 0 otherwise.

DUMMY_COVENANT

Equals 1 if a loan obtained by a firm in year $t$ contains at least one covenant requirement, and 0 otherwise.

COVENANT_INTENSITY,

The natural logarithm of 1 plus the total number of covenants in the loan facility a firm obtains in year $t$.

LOAN_PURPOSE_DUMMIES

Dummy variables for loan purposes, including corporate purposes, debt repayment, working capital, acquisitions, backup loans, and miscellaneous.

LOAN_TYPE_DUMMIES

Dummy variables for loan types, including term loan, revolver greater than 1 year, revolver less than 1 year, 364-day facility, bridge loans, and miscellaneous.

Panel B. County-Level Variables (based on county-year data in year $t-1$ )

SOCIAL_CAPITAL $t-1 \quad$ The first principal component of a PCA based on NRCRD data in year $t-1$, the year immediately prior to a year in which a firm obtains a bank loan. The Appendix describes the estimation procedure and the requisite NRCRD data used in the PCA.

$\ln \left(\operatorname{INCOME}_{t-1}\right)$ Natural logarithm of the median household income per capita in a county in year $t-1$.

In(POPULATION $\left.{ }_{t-1}\right)$ Natural logarithm of the population size of a county in year $t-1$.

$\ln \left(\right.$ EDUCATION $\left._{t-1}\right)$

Natural logarithm of the fraction of people 25 years old and above with at least 1 year of college education in a county in year $t-1$.

$\ln \left(\mathrm{AGE}_{t-1}\right)$ Natural logarithm of the median age of the residents in a county in year $t-1$.

Panel C. Firm-Level Variables (based on firm-year data in year $t-1$ )

$\ln \left(\right.$ ASSETS $\left._{t-1}\right)$

PROFITABILITY $Y_{t-1}$

$\mathrm{MB}_{t-1}$

LEVERAGE $_{t-1}$

TANGIBILITY ${ }_{t-1}$ ZSCORE $_{t-1}$

CASH_HOLDING $t-1$ EARNINGS_VOLATILITY ${ }_{t-1}$ SALES_GROWTH $H_{t-1}$
Natural logarithm of total assets for a firm at the beginning of year $t-1$.

Net income/total assets in year $t-1$.

Market-to-book ratio for a firm in year $t-1$, measured as market value of equity $($ PRCC_F $\times$ CSHO), scaled by book value of equity (CEQ).

Leverage for a firm in year $t-1$, measured as long-term debt scaled by lagged assets.

Net property, plant, and equipment/total assets in year $t-1$.

Modified Altman's (1968) $Z$-score in year $t-1$. $Z$-score is computed as (1.2 working capital +1.4 retained earnings $+3.3 \mathrm{EBIT}+0.999$ sales $) /$ total assets. We follow Graham et al. (2008) in using this modified $Z$-score, which does not include the ratio of market value of equity to book value of total debt, because a similar term, market-to-book (MB), enters our regressions as a separate control variable.

Cash and marketable securities divided by total assets in year $t-1$.

The standard deviation of quarterly earnings in the 3 years prior to the year in which the firm obtained a loan (i.e., from year $t-3$ to year $t-1$ ).

The percentage growth rate of sales from 2 years prior to the year immediately before the year of loan inception. 
We use a modified specification of the baseline model to test Hypothesis 2 . Specifically, we replace the dependent variable that captures loan spreads with alternate variables that capture the use of nonprice loan terms, such as collateral and covenants. Additionally, we use alternate specifications derived from the baseline model to examine other hypotheses concerning the effect of social capital on atissue bond yield spreads and the effect of social capital on the choice of debt financing. We discuss the specifications of these models in Section VI.

\section{Sample Selection and Summary Statistics}

We construct the sample using data from various sources. We obtain information for loan facilities of U.S. firms from the Thomson Reuters LPC DealScan database. We treat each loan facility as a distinct observation, because loan terms could differ across the different facilities that a firm obtains in a given year. We rely on Standard \& Poor's (S\&P) Compustat database for the corresponding financial data and information on company headquarters location. ${ }^{6}$ We use the state and county name of each firm's headquarters location to match Compustat data with social capital data from the NRCRD and demographic data from the Bureau of Economic Analysis. The NRCRD provides county-level social capital data for four different years in 1990, 1997, 2005, and 2009. Thus, we fill in the data for the missing years using the social capital measure in the preceding year for which data are available. For example, we fill in missing data from 1998 to 2004 using the social capital measure in 1997. Gompers, Ishii, and Metrick (2003) and Hilary and Hui (2009) use a similar practice to fill in missing-year data for antitakeover provisions and local religiosity, respectively. The final sample contains 32,425 loan-year observations for 5,678 unique firms with headquarters located in 587 unique U.S. counties in the period 1990-2012 for which complete data are available from all sources.

Table 2 reports descriptive statistics for all variables used in estimating the baseline model. On average, the loan spread and the loan size in our sample are 199 bps and $\$ 305$ million, respectively. Approximately 53\% of the sampled loan facilities have a collateral requirement. Approximately $62 \%$ of the sampled loans have at least one covenant in place; on average, these loans have around four covenants. The characteristics of the loans in our sample are in the range of those reported by Valta (2012) and Hasan et al. (2014).

\section{The Relation between Social Capital and the Cost of Bank Loans}

\section{A. Baseline Regression Results}

We estimate the baseline model using ordinary least squares (OLS) regressions with standard errors adjusted for heteroskedasticity and within-firm clustering. We adjust standard errors for within-firm clustering because a firm could obtain multiple facilities or loans during the sample period. Table 3 presents the

\footnotetext{
${ }^{6}$ Compustat reports the latest location of the firm's headquarters. This creates a potential matching problem for firms that relocated their headquarters to other counties during the sample period. We resolve this issue by obtaining the firm's historical headquarters addresses using 10-K filings from the U.S. Securities and Exchange Commission.
} 
TABLE 2

Summary Statistics

Table 2 reports the summary statistics for variables in the baseline model. The sample contains 32,425 loan-year observations during the period 1990-2012. SOCIAL_CAPITAL $t-1$ is an index variable that captures the joint effect of social networks and cooperative norms across U.S. counties using information from year $t-1$, the year that immediately precedes a year in which a firm obtains a loan. It is based on data provided by the NRCRD at Pennsylvania State University. The Appendix discusses the NRCRD data and the corresponding variable-construction procedure. Other county-level attributes are computed using year $t-1$ data from the Bureau of Economic Analysis. Firm characteristics are computed using year $t-1$ data from the S\&P Compustat database. Loan characteristics are computed using loan-year data from the Thomson Reuters LPC DealScan database as of year $t$. Table 1 defines other variables.

\begin{tabular}{|c|c|c|c|c|c|c|}
\hline \multirow[b]{2}{*}{ Variables } & \multirow[b]{2}{*}{$N$} & \multirow[b]{2}{*}{ Mean } & \multirow[b]{2}{*}{ Std. Dev. } & \multicolumn{3}{|c|}{ Percentiles } \\
\hline & & & & P25 & P50 & P75 \\
\hline SOCIAL_CAPITAL $t_{t-1}$ & 32,425 & -0.537 & 0.868 & -1.193 & -0.484 & 0.059 \\
\hline \multicolumn{7}{|l|}{$\underline{\text { Panel A. Firm Attributes }}$} \\
\hline $\begin{array}{l}\text { In(ASSETS } t-1 \text { ) } \\
\text { PROFITABILITY }_{t-1} \\
\text { MB }_{t-1} \\
\text { LEVERAGE }_{t-1} \\
\text { TANGIBILITY }_{t-1} \\
\text { ZSCORE }_{t-1} \\
\text { CASH_HOLDING }_{t-1} \\
\text { EARNINGS_VOLATILITY }_{t-1} \\
\text { SALES_GROWTH }_{t-1}\end{array}$ & $\begin{array}{l}32,425 \\
32,425 \\
32,425 \\
32,425 \\
32,425 \\
32,425 \\
32,425 \\
32,425 \\
32,425\end{array}$ & $\begin{array}{l}6.677 \\
0.017 \\
2.413 \\
0.343 \\
0.301 \\
1.542 \\
0.087 \\
0.509 \\
0.221\end{array}$ & $\begin{array}{l}2.152 \\
0.171 \\
3.728 \\
0.254 \\
0.244 \\
1.629 \\
0.126 \\
0.649 \\
0.507\end{array}$ & $\begin{array}{l}5.145 \\
0.001 \\
1.110 \\
0.168 \\
0.097 \\
0.944 \\
0.014 \\
0.162 \\
0.036\end{array}$ & $\begin{array}{l}6.591 \\
0.035 \\
1.823 \\
0.316 \\
0.240 \\
1.510 \\
0.038 \\
0.310 \\
0.088\end{array}$ & $\begin{array}{l}8.075 \\
0.081 \\
3.091 \\
0.468 \\
0.458 \\
2.275 \\
0.104 \\
0.540 \\
0.238\end{array}$ \\
\hline \multicolumn{7}{|l|}{$\underline{\text { Panel B. Loan Attributes }}$} \\
\hline $\begin{array}{l}\text { SPREAD }_{t} \\
\text { DUMMY_COLLATERAL }_{t} \\
\text { DUMMY_COVENANT }_{t} \\
\text { COVENANT_INTENSITY }_{t} \\
\text { LOAN_SIZE }_{t} \\
\text { MATURITY }_{t} \\
\text { DUMMY_SYNDICATION }_{t} \\
\text { DEBT_RATING }_{t}\end{array}$ & $\begin{array}{l}32,425 \\
32,425 \\
32,425 \\
20,159 \\
32,425 \\
32,425 \\
32,425 \\
32,425\end{array}$ & $\begin{array}{r}199 \\
0.530 \\
0.621 \\
4.178 \\
305 \\
43.377 \\
0.836 \\
5.991\end{array}$ & $\begin{array}{r}141 \\
0.499 \\
0.486 \\
2.207 \\
760 \\
26.467 \\
0.371 \\
1.386\end{array}$ & $\begin{array}{r}87 \\
0.000 \\
0.000 \\
2.000 \\
25 \\
22 \\
1.000 \\
5.000\end{array}$ & $\begin{array}{r}175 \\
1.000 \\
1.000 \\
4.000 \\
100 \\
40 \\
1.000 \\
7.000\end{array}$ & $\begin{array}{r}275 \\
1.000 \\
1.000 \\
6.000 \\
300 \\
60 \\
1.000 \\
7.000\end{array}$ \\
\hline \multicolumn{7}{|l|}{ Panel C. County Attributes } \\
\hline $\begin{array}{l}\text { In }\left(\text { INCOME }_{t-1}\right) \\
\text { In(POPULATION } \\
\text { In(EDUCATION } \\
\left.\text { In } \text { EDE }_{t-1}\right) \\
\text { In }\left(\text { AGE }_{t-1}\right)\end{array}$ & $\begin{array}{l}32,425 \\
32,425 \\
32,425 \\
32,425\end{array}$ & $\begin{array}{r}10.453 \\
13.659 \\
3.340 \\
3.524\end{array}$ & $\begin{array}{l}0.337 \\
1.077 \\
0.313 \\
0.073\end{array}$ & $\begin{array}{r}10.232 \\
13.193 \\
3.178 \\
3.478\end{array}$ & $\begin{array}{r}10.395 \\
13.660 \\
3.325 \\
3.517\end{array}$ & $\begin{array}{r}10.643 \\
14.244 \\
3.538 \\
3.575\end{array}$ \\
\hline
\end{tabular}

estimated coefficients. Across all models, the dependent variable is $\ln$ (SPREAD), and the test variable is SOCIAL_CAPITAL. Model 1 includes firm-level controls. Model 2 includes firm-level and loan-level controls. Model 3 contains firm-level, loan-level, and county-level controls. Model 4 is the baseline model, which includes loan-level, firm-level, and county-level controls and dummies to control for state fixed effects. The estimates on SOCIAL_CAPITAL across all models are negative and significant. They are $-0.026,-0.020,-0.034$, and -0.025 for models $1,2,3$, and 4, respectively. These results suggest that firms with headquarters located in U.S. counties with higher levels of social capital incur significantly lower bank loan costs after controlling for firm, loan, and county characteristics. These results are consistent with Hypothesis 1.

Based on the estimate in model 4 of Table 3, and given that the average loan spread in our sample is 199 bps, a 1-standard-deviation increase in SOCIAL_CAPITAL in the data reduces loan spreads by approximately $4.33 \mathrm{bps}^{7}$

\footnotetext{
${ }^{7}$ A 1-standard-deviation increase in SOCIAL_CAPITAL (i.e., 0.868 in Table 2) leads to a reduction in $\ln (\mathrm{SPREAD})$ of approximately -0.022 , where $-0.022=-0.025 \% \times 0.868$, which, in turn, implies a decrease of 4.33 bps based on the average loan spread of 199 bps in the sample $(-4.33=199 \times$ $\exp (-0.022)-199)$.
} 
TABLE 3

Baseline Regressions: The Effect of Social Capital on Loan Spread

The sample contains 32,425 loan-year observations during the period 1990-2012. Model 1 of Table 3 includes controls for firm characteristics. Model 2 adds additional controls for loan characteristics. Model 3 adds additional controls for county demographical factors. Model 4 is the baseline model of equation (1). It includes controls for state fixed effects in addition to county-level demographic factors and firm and loan characteristics. Across all models, the dependent variable is $\operatorname{In}\left(\operatorname{SPREAD}{ }_{t}\right)$. It is the natural logarithm of the all-in loan spread drawn in basis points for a loan that a firm obtains in year $t$. SOCIAL_CAPITAL $t-1$ captures the joint effect of social networks and cooperative norms across U.S. counties using information from year $t-1$. Table 1 defines other variables. Standard errors are adjusted for heteroskedasticity and within-firm clustering. $t$-statistics are reported in parentheses. ${ }^{*},{ }^{* *}$, and ${ }^{* * *}$ indicate significance at the $10 \%, 5 \%$, and $1 \%$ levels, respectively.

\begin{tabular}{|c|c|c|c|c|}
\hline \multirow{2}{*}{ Variables } & & & & \\
\hline & 1 & 2 & 3 & 4 \\
\hline SOCIAL_CAPITAL $L_{t-1}$ & $\begin{array}{l}-0.026^{\star \star} \\
(-2.38)\end{array}$ & $\begin{array}{l}-0.020^{* *} \\
(-2.34)\end{array}$ & $\begin{array}{l}-0.034^{\text {***}} \\
(-3.48)\end{array}$ & $\begin{array}{l}-0.025^{\star *} \\
(-2.25)\end{array}$ \\
\hline $\ln \left(\right.$ ASSETS $\left._{t-1}\right)$ & $\begin{array}{l}-0.247^{\star \star \star} \\
(-35.29)\end{array}$ & $\begin{array}{l}-0.096^{\star \star \star} \\
(-12.97)\end{array}$ & 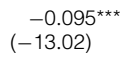 & $\begin{array}{l}-0.095^{\text {*** }}(-13.13) \\
(-10\end{array}$ \\
\hline PROFITABILITY $Y_{t-1}$ & $\begin{array}{l}-0.378^{\star \star \star} \\
(-10.36)\end{array}$ & $\begin{array}{l}-0.318^{\star \star \star} \\
(-11.27)\end{array}$ & $\begin{array}{l}-0.319^{\star \star \star *} \\
(-11.27)\end{array}$ & $\begin{array}{l}-0.321^{\text {}} \\
(-11.41)\end{array}$ \\
\hline $\mathrm{MB}_{t-1}$ & $\begin{array}{l}-0.011^{\star \star \star} \\
(-5.76)\end{array}$ & $\begin{array}{l}-0.006^{\star \star \star} \\
(-4.15)\end{array}$ & $\begin{array}{l}-0.006^{\star \star \star} \\
(-4.19)\end{array}$ & $\begin{array}{l}-0.006^{\star \star \star} \\
(-4.20)\end{array}$ \\
\hline LEVERAGE $_{t-1}$ & $\begin{array}{l}0.627^{\star \star \star} \\
(15.28)\end{array}$ & $\begin{array}{l}0.441^{\star \star \star} \\
(14.34)\end{array}$ & $\begin{array}{c}0.442^{* * *} \\
(14.33)\end{array}$ & $\begin{array}{l}0.443^{\text {*** }} \\
(14.49)\end{array}$ \\
\hline TANGIBILITY $_{t-1}$ & 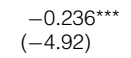 & 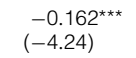 & $\begin{array}{l}-0.161^{\text {*** }} \\
(-4.22)\end{array}$ & $\begin{array}{l}-0.168^{\text {***}} \\
(-4.44)\end{array}$ \\
\hline $\mathrm{ZSCORE}_{t-1}$ & $\begin{array}{l}-0.027^{\star \star \star} \\
(-4.96)\end{array}$ & $\begin{array}{l}-0.022^{\star \star \star} \\
(-5.52)\end{array}$ & $\begin{array}{l}-0.022^{\star \star \star} \\
(-5.41)\end{array}$ & $\begin{array}{l}-0.022^{\star \star \star} \\
(-5.51)\end{array}$ \\
\hline CASH_HOLDING ${ }_{t-1}$ & 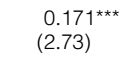 & $\begin{array}{l}0.092^{*} \\
(1.91)\end{array}$ & $\begin{array}{l}0.090^{*} \\
(1.86)\end{array}$ & $\begin{array}{c}0.093^{*} \\
(1.94)\end{array}$ \\
\hline EARNINGS_VOLATILITY $Y_{t-1}$ & $\begin{array}{l}0.149^{\star \star \star} \\
(11.65)\end{array}$ & $\begin{array}{l}0.107^{\star \star \star} \\
(11.53)\end{array}$ & $\begin{array}{l}0.108^{\text {***}} \\
(11.63)\end{array}$ & $\begin{array}{l}0.108^{* \star \star} \\
(11.69)\end{array}$ \\
\hline SALES_GROWTH $H_{t-1}$ & $\begin{array}{l}0.072^{\star \star \star} \\
(6.02)\end{array}$ & $\begin{array}{l}0.038^{\star \star \star} \\
(3.94)\end{array}$ & $\begin{array}{l}0.038^{\star \star \star} \\
(3.91)\end{array}$ & $\begin{array}{l}0.036^{\star \star \star} \\
(3.78)\end{array}$ \\
\hline In(LOAN_SIZE $\left.{ }_{t}\right)$ & & $\begin{array}{l}-0.106^{\star \star \star} \\
(-16.76)\end{array}$ & $\begin{array}{l}-0.105^{\star \star \star} \\
(-16.81)\end{array}$ & $\begin{array}{l}-0.106^{\text {*** }} \\
(-17.20)\end{array}$ \\
\hline $\operatorname{In}\left(\right.$ MATURITY $\left._{t}\right)$ & & $\begin{array}{l}-0.048^{\star \star \star} \\
(-4.83)\end{array}$ & $\begin{array}{l}-0.048^{\star \star \star} \\
(-4.84)\end{array}$ & $\begin{array}{l}-0.048^{* \star *} \\
(-4.84)\end{array}$ \\
\hline DUMMY_SYNDICATION ${ }_{t}$ & & $\begin{array}{l}-0.050^{\text {***}} \\
(-3.41)\end{array}$ & $\begin{array}{l}-0.051^{\text {*** }} \\
(-3.45)\end{array}$ & $\begin{array}{l}-0.052^{\text {** }} \\
(-3.54)\end{array}$ \\
\hline DEBT_RATING ${ }_{t}$ & & $\begin{array}{l}0.118^{\star \star \star} \\
(17.52)\end{array}$ & $\begin{array}{l}0.118^{\star \star \star} \\
(17.58)\end{array}$ & $\begin{array}{l}0.118^{\star \star \star} \\
(17.62)\end{array}$ \\
\hline $\ln \left(\mathrm{INCOME}_{t-1}\right)$ & & & $\begin{array}{l}-0.040 \\
(-0.83)\end{array}$ & $\begin{array}{l}-0.016 \\
(-0.31)\end{array}$ \\
\hline $\ln \left(\right.$ POPULATION $\left._{t-1}\right)$ & & & $\begin{array}{l}-0.014^{*} \\
(-1.79)\end{array}$ & $\begin{array}{l}-0.007 \\
(-0.86)\end{array}$ \\
\hline $\ln \left(\mathrm{EDUCATION}_{t-1}\right)$ & & & $\begin{array}{c}0.063 \\
(1.57)\end{array}$ & $\begin{array}{c}0.047 \\
(1.13)\end{array}$ \\
\hline $\ln \left(\mathrm{AGE}_{t-1}\right)$ & & & $\begin{array}{c}0.162 \\
(1.56)\end{array}$ & $\begin{array}{l}0.184 \\
(1.45)\end{array}$ \\
\hline $\begin{array}{l}\text { Loan-purpose and loan-type fixed effects } \\
\text { Industry and year fixed effects } \\
\text { State fixed effects }\end{array}$ & $\begin{array}{l}\text { No } \\
\text { Yes } \\
\text { No }\end{array}$ & $\begin{array}{l}\text { Yes } \\
\text { Yes } \\
\text { No }\end{array}$ & $\begin{array}{l}\text { Yes } \\
\text { Yes } \\
\text { No }\end{array}$ & $\begin{array}{l}\text { Yes } \\
\text { Yes } \\
\text { Yes }\end{array}$ \\
\hline $\begin{array}{l}\text { No. of obs. } \\
\text { Adj. } R^{2}\end{array}$ & $\begin{array}{r}32,425 \\
0.469\end{array}$ & $\begin{array}{r}32,425 \\
0.612\end{array}$ & $\begin{array}{r}32,425 \\
0.613\end{array}$ & $\begin{array}{r}32,425 \\
0.615\end{array}$ \\
\hline
\end{tabular}

The loan size and the time to maturity in the sample, on average, are \$305 million and around 4 years, respectively. Taken together, this implies that a 1-standarddeviation increase in SOCIAL_CAPITAL reduces total interest expenses per loan facility by $\$ 0.528$ million $(0.528=305 \times 0.000433 \times 4)$. The effect of social capital on bank loan cost is economically meaningful. Our estimate is consistent with those reported in prior studies. For example, Bharath et al. (2008), Francis, 
Hasan, Koetter, and Wu (2012), and Hasan et al. (2014) find that a 1-standarddeviation increase in accounting quality, board independence, and cash effective tax rate (CETR) in their respective samples reduces loan spreads by $6.65,5.50$, and $4.87 \mathrm{bps}$, respectively. ${ }^{8}$

\section{B. Sensitivity Tests}

This section reports the results from several analyses that establish the robustness of our findings based on bank loan spreads.

\section{Additional Controls}

Cai and Shi (2014) and Jiang et al. (2014) find that firms located in areas with strong local religiosity vis-à-vis stronger religious norms and dense religious networks, incur lower cost of debt. Goss and Roberts (2011) find that firms engaging in corporate activities that are detrimental to stakeholders incur higher-interest spreads when obtaining bank loans. Bharath et al. (2008) find that firms with poor accounting quality have higher bank loan costs. Hasan et al. (2014) show that banks charge higher loan spreads when lending to firms that are aggressive in avoiding corporate taxes.

We add four additional control variables to the baseline model to ensure that our results are robust to the inclusion of these factors. RELIGIOUS ADHERENCE is the fraction of a county's population that claims affiliation with an organized religion. DS400 is a dummy variable that equals 1 if a firm belongs to the Domini 400 Social Index, and 0 otherwise. The Domini Social Index includes publicly traded companies that are considered socially responsible because they meet certain standards of social and environmental excellence. DISCRETIONARY_ACCRUAL is the abnormal discretionary accrual measure (Dechow, Sloan, and Sweeney (1995)), which is based on the modified Jones (1991) model. CETR measures the extent to which a firm engages in tax avoidance. CETR is calculated as cash tax paid (TXPD) divided by pretax book income (PI) less special items (SPI). It is inversely related to tax avoidance.

Data requirements for these additional control variables reduce the sample size to around 20,000 loan-year observations, representing a reduction of approximately $35 \%$. Model 1 of Table 4 reports the results. Despite the reduction in sample size, the coefficient on SOCIAL_CAPITAL remains negative and statistically significant, and the magnitude of the estimate is comparable to those reported in Table 3.

\section{Alternative Measure of Social Capital}

We also explore whether our findings are robust to an alternative measure of social capital. Guiso et al. (2004) and Buonanno et al. (2009) use blood and organ donation as an alternate proxy for social capital. Following these

\footnotetext{
${ }^{8}$ If banks perceive firms located in communities with higher levels of social capital as more trustworthy, then our results suggest that perceived trustworthiness reduces the cost of bank loan contracting. In this way, our results confirm those reported by Duarte, Siegel, and Young (2012), although we explore the issue in a different market setting and use a different proxy to capture trustworthiness. Duarte et al. (2012) examine how peer-to-peer lending outcomes are associated with perceived trustworthiness as captured by the appearance of the borrower's photograph. They find that a trustworthy individual borrower can receive a significantly lower interest rate than a less trustworthy borrower, holding other factors constant.
} 
Samples across the models differ due to changing data requirements. In all models of Table 4, the dependent variable is $\ln \left(\mathrm{SPREAD}_{t}\right)$, which is the natural logarithm of the all-in loan spread drawn in basis points for a loan that a firm obtains in year $t$, and we use the same control variables as specified in the baseline model of equation (1) to isolate the effects of firm, loan, and county demographic attributes; industry, year, and state fixed effects; and loan purposes and types. SOCIAL_CAPITAL $t_{t-1}$ is the test variable in models 1 and 4 . Models 2 and 3 use alternate variables to capture the effect of social capital. In model 1, four additional variables are included to isolate the effects of local religiosity, corporate social responsibility, accounting quality, and corporate tax avoidance. These variables are as of year $t-1$. RELIGIOUS_ADHERENCE $E_{t-1}$ is the fraction of a county's population that claims affiliation with an organized religion. $\mathrm{DS}_{400_{t-1}}$ is an indicator variable that equals 1 if a firm is in the Domini 400 Social Index, and 0 otherwise. The Domini Social Index includes publicly traded companies that meet certain standards of social and environmental excellence. DISCRETIONARY_ACCRUAL $t_{t-1}$ is a measure that captures the level of a firm's abnormal discretionary accruals (Dechow et al. (1995)). Cash effective tax rate, CETR $t_{t-1}$, is cash tax paid (TXPD) divided by pretax book income (PI) less special items (SPI). In model 2, we use ORGAN_DONATION ${ }_{t-1}$ as an alternate measure to capture the effect of social capital. ORGAN_DONATION ${ }_{t-1}$ is the state-level per capita registered organ donor multiplied by 1,000. In model 3, we use a linear interpolation method to estimate the level of social capital in U.S. counties for years with missing NRCRD data and use the corresponding estimate, INTERPOL_SOCIAL_CAPITAL ${ }_{t-1}$, as an alternate measure of social capital. In model 4 , we estimate the baseline model based on a reduced sample that consists only of loans borrowed by a firm from a bank for the first time. Standard errors are adjusted for heteroskedasticity and within-firm clustering. $t$-statistics are reported in parentheses. ${ }^{*},{ }^{* *}$, and ${ }^{* * *}$ indicate significance at the $10 \%, 5 \%$, and $1 \%$ levels, respectively.

\begin{tabular}{|c|c|c|c|c|}
\hline \multirow[b]{2}{*}{ Variables } & \multicolumn{4}{|c|}{ Dependent Variable: In(SPREAD $\left.{ }_{t}\right)$} \\
\hline & 1 & 2 & 3 & 4 \\
\hline SOCIAL_CAPITAL $t-1$ & $\begin{array}{l}-0.021^{*} \\
(-1.78)\end{array}$ & & & $\begin{array}{l}-0.055^{\text {***}} \\
(-4.16)\end{array}$ \\
\hline ORGAN_DONATION ${ }_{t-1}$ & & $\begin{array}{l}-0.102^{\star \star} \\
(-2.03)\end{array}$ & & \\
\hline INTERPOL_SOCIAL_CAPITAL ${ }_{t-1}$ & & & $\begin{array}{l}-0.032^{* *} \\
(-2.18)\end{array}$ & \\
\hline RELIGIOUS_ADHERENCE ${ }_{t-1}$ & $\begin{array}{l}-0.033^{\star \star \star} \\
(-5.03)\end{array}$ & & & \\
\hline DS400 $t-1$ & $\begin{array}{l}-0.199^{\star \star \star} \\
(-6.27)\end{array}$ & & & \\
\hline DISCRETIONARY_ACCRUAL ${ }_{t-1}$ & $\begin{array}{c}0.003 \\
(1.37)\end{array}$ & & & \\
\hline $\mathrm{CETR}_{t-1}$ & $\begin{array}{l}-0.130^{\star \star \star} \\
(-4.77)\end{array}$ & & & \\
\hline All control variables & Yes & Yes & Yes & Yes \\
\hline $\begin{array}{l}\text { No. of obs. } \\
\text { Adj. } R^{2}\end{array}$ & $\begin{array}{r}20,715 \\
0.620\end{array}$ & $\begin{array}{r}31,114 \\
0.615\end{array}$ & $\begin{array}{r}26,155 \\
0.626\end{array}$ & $\begin{array}{l}7,964 \\
0.585\end{array}$ \\
\hline
\end{tabular}

authors, we use the organ donation data from the Organ Procurement and Transplantation Network (OPTN) to construct an alternative measure of social capital in the United States. We obtain the annual total number of organ donors in each state from OPTN and define ORGAN_DONATION as the state-level per capita organ donor multiplied by $1,000 .{ }^{9}$ We estimate the baseline model using ORGAN_DONATION as the test variable in place of SOCIAL_CAPITAL. Model 2 of Table 4 reports the results. The estimate on ORGAN_DONATION is negative and significant, suggesting that our finding is robust to the alternative measure of social capital.

\footnotetext{
${ }^{9}$ State-level per capita organ donor is the total number of organ donors in a state in a given year divided by total state population in that year. A donor is a person from whom at least one organ or tissue is recovered for the purpose of transplantation. Organ donation data can be obtained from OPTN via the link https://optn.transplant.hrsa.gov/data/. The data for some states with smaller populations, such as Alaska, Delaware, Idaho, and New Hampshire, are missing. Therefore, we have fewer observations for the analysis when we use ORGAN_DONATION as an alternative social capital measure.
} 


\section{Other Robustness Checks}

When we construct the SOCIAL_CAPITAL variable, we fill in data for the missing years using values of the social capital variable in the preceding year for which data are available. This procedure could affect our estimation. Following Hilary and Hui (2009), we use a linear interpolation method to estimate the missing-year data in the SOCIAL_CAPITAL variable. This produces an alternate measure for social capital, INTERPOL_SOCIAL_CAPITAL, which we use in place of the original SOCIAL_CAPITAL variable before we reestimate the baseline model. We are able to construct the INTERPOL_SOCIAL_CAPITAL variable up to 2009 because that is the last year in which raw data from the NRCRD are available. Consequently, the sample size reduces to around 26,000 loan-year observations. Model 3 of Table 4 presents results from this regression. Results are consistent with those in the baseline regression; the coefficient on INTERPOL_SOCIAL_CAPITAL is both negative and significant.

Bharath, Dahiya, Saunders, and Srinivasan (2011) find that a prior borrowing-lending relationship reduces loan spreads when the firm engages the same bank in another loan transaction. In our study, the social capital measure captures both social norms and social networks, and the social network component is more likely to reflect the overall environmental connections of the firm with local communities instead of the connection between borrowers and lenders. Nonetheless, we conduct a robustness test to mitigate the concern that our findings are driven by the relationship between borrowing firms and banks (Engelberg et al. (2012)). We create a reduced sample in which we only include loans that a firm borrows from a specific lead bank for the first time. In other words, all the subsequent loans borrowed by a borrower from the same lead bank are excluded from the sample, ensuring that repeated borrowing-lending relationships do not confound our results. We estimate the baseline regression using this reduced sample of 7,964 first-time loans and report the results in model 4 of Table 4 . We continue to find a negative and statistically significant coefficient on the SOCIAL_CAPITAL variable, suggesting that our main finding is not driven by the relationship lending between borrowers and banks.

\section{Identification Strategies}

We view social capital as an external institution that exerts exogenous pressure that constrains opportunistic firm behaviors in debt contracting, which, in turn, lowers the specter of the moral hazards banks face in debt contracting and, consequently, causes banks to lower loan spreads when extending credit to firms with headquarters located in counties with higher levels of social capital. In this section, we use a quasi-experiment and an instrumental-variable 2-stage regression approach to identify the causal effect of social capital on the cost of bank loans.

\section{A. Difference-in-Differences Analysis of Social-Capital-Changing Corporate Relocations}

Social-capital-changing relocations are corporate headquarters relocation events that change the level of social capital facing the firm. These events 
provide an ideal empirical setting to identify the causal effect of social capital on loan spreads. If a higher level of social capital causes banks to reduce loan spreads, firms with a social-capital-increasing relocation (i.e., firms that relocate to a county with a higher level of social capital) should experience a reduction in loan spreads for the loans they obtain after the relocation relative to the loans they obtain before the relocation. In contrast, firms with a social-capital-decreasing relocation should experience an increase in loan spreads for the loans they obtain after the relocation relative to the loans they obtain before the relocation. Taken together, these effects imply that the difference in changes in loan spreads before and after the relocation event should be significantly lower for firms with a social-capital-increasing relocation when compared with firms with a socialcapital-decreasing relocation.

We search U.S. Securities and Exchange Commission (SEC) 10-K filings for corporate headquarters addresses. A social-capital-changing relocation event is identified if a firm reports headquarters addresses located in two different counties in its $10-\mathrm{K}$ filings across 2 consecutive years. In order to be included in the testing sample, we require that firms identified with relocation events have obtained at least one loan facility in both the pre- and post-relocation periods. In addition, we require that firms have 2 years of data available in both time periods, before and after the year of the relocation event. For example, pre-relocation data for 1993 and 1994 are required if the firm relocates in 1995, and post-relocation data for 2011 and 2012 are required if the firm relocates in 2010.

Because electronic SEC filings began in 1993, we limit our sample of socialcapital-changing relocation events to a period starting in 1995 and ending in 2010. To avoid confounding event windows, we remove firms with multiple relocations. The final sample contains 229 firms with a single social-capital-changing relocation during 1995-2010. For the 229 relocation firms in the final sample, we collect the loan-year data straddling the relocation year, excluding the data in the year of the relocation, because the level of social capital is changing in that year. The final sample consists of 1,778 loan-year observations during the period 1993-2012. Of these, 976 are from the pre-relocation period, and 802 are from the post-relocation period.

We use a difference-in-differences test to examine the causal effect of social capital on bank loan cost. Accordingly, we modify the baseline model by adding POST, SOCIAL_CAPITAL_INCREASING_RELOCATION, and their interaction variable in place of the social capital measure. POST equals 1 for observations in the post-relocation period, and it equals 0 for observations in the pre-relocation period. SOCIAL_CAPITAL_INCREASING_RELOCATION equals 1 if a firm relocated its headquarters to a county with a higher level of social capital; it equals 0 if a firm relocated its headquarters to a county with a lower level of social capital. In addition, we also remove the control variables that isolate the year fixed effect from the regression model, because the POST variable should partially subsume the year effect in this estimation procedure. Nevertheless, because we observe some clustering in the distribution over time, particularly in the 4-year period from 1997 to 2000, we also estimate the models after including year dummies to isolate the year fixed effect in the estimation. We find that the results are qualitatively unchanged; we do not tabulate these results. 
Our main focus is the coefficient on the interaction term, POST $\times$ SOCIAL_CAPITAL_INCREASING_RELOCATION, because it captures the difference-in-differences effect on the changes over time in loan spreads between firms with a social-capital-increasing relocation and firms with a social-capitaldecreasing relocation around the relocation events. Panel A of Table 5 reports the regression results. Model 1 reports the regression results from the full sample of 1,778 firm-year observations. Model 2 limits the sample observations to a shorter event window, which defines the pre-relocation (post-relocation) period as the 4 years before (after) the relocation event. This procedure results in a sample of 952 observations. We maintain the same data requirements in both samples; more specifically, we require that firms have obtained at least one loan facility in both the pre- and post-relocation periods in both samples. The coefficients on the interaction term are -0.128 and -0.125 , respectively, and they are statistically significant. These results indicate that banks demand significantly lower loan spreads after the relocation event when lending to firms with social-capital-increasing relocations when compared to firms with social-capital-decreasing relocations. The findings indicate that social-capital-changing relocations provide banks with incremental information about the specter of the moral hazards they face in debt contracting. They lend credence to the argument that social capital causes banks to adjust the cost of bank loans when extending credit to their client firms.

An underlying assumption of the difference-in-differences analysis is that the two groups of firms in comparison have similar characteristics. We verify that this condition is met. We conduct $t$-tests to examine whether the loan-spread and firm-characteristics variables in the year immediately prior to the relocation event are systematically different across the two samples: the sample of firms with a social-capital-increasing relocation and the sample of firms with a social-capitaldecreasing relocation. The results in Panel B of Table 5 reveal no significant differences in loan spread and firm characteristics between the two groups of firms. These results provide more confidence that the difference-in-differences estimate reflects a causal effect of social capital on loan spread.

Nevertheless, with respect to the geographical distribution of the sample, we find that most moves involve a headquarters relocation across states (i.e., out-ofstate move) rather than a relocation that moves the firm's headquarters to a different county within the same state (i.e., in-state move). There are 145 out-of-state moves and 84 in-state moves in our sample. Further, firms with social-capitalincreasing relocations are less likely to move their headquarters across states (i.e., less likely to have out-of-state moves).$^{10}$ In an untabulated robustness check, we examine the extent to which these associations confound our analysis by including an additional dummy variable in the difference-in-differences regressions to control for incidences of out-of-state moves. We find that our results are robust to this alternate specification.

\footnotetext{
${ }^{10}$ Of the 107 firms with social-capital-increasing relocations, we find that 61 firms, or $57 \%$ of the sample, moved their headquarters across states. In contrast, among the 122 firms with social-capitaldecreasing relocations, we find that 84 firms, or $68.5 \%$ of the sample, moved their headquarters across states. Additionally, the null hypothesis that these proportions are equal is rejected based on the $\chi^{2}$ test $(p$-value $=0.03)$.
} 


\section{TABLE 5 \\ Evidence from a Quasi-Experiment: Firms with Social-Capital-Changing Headquarters Relocations}

Panel A of Table 5 reports the results of a difference-in-differences analysis based on the quasi-experiment. The dependent variable is $\operatorname{In}\left(S P R E A D_{t}\right)$, which is the natural logarithm of the all-in loan spread drawn in basis points for a loan that a firm obtains in year $t$, and we use the same control variables as specified in the baseline model of equation (1) to isolate the effects of firm, loan, and county demographic attributes; industry and state fixed effects; and loan purposes and types. Model 1 uses a sample of 229 firms with a headquarters relocation event during the period 1995-2010 and 1,778 corresponding loan facilities these firms obtained before and after the relocation event. Model 2 uses a reduced sample of 190 firms and 952 corresponding loan facilities during the 4-year period before and the 4-year period after the relocation event. POST equals 1 if the observation is after the relocation event; it equals 0 if the observation is before the relocation event. SOCIAL_CAPITAL_INCREASING_RELOCATION equals 1 if a firm relocates its headquarters to a county with a higher level of social capital; it equals 0 if a firm relocates to a county with a lower level of social capital. Table 1 provides definitions for other variables. Standard errors are adjusted for heteroskedasticity and within-firm clustering. $t$-statistics are reported in parentheses. *, ${ }^{*}$, and ${ }^{* *}$ indicate significance at the $10 \%, 5 \%$, and $1 \%$ levels, respectively. Panel B reports mean values, standard deviations, and student $t$-statistics for a difference in the mean values of loan spread and all firm attributes across the two respective samples, namely, firms with social-capital-increasing relocations and firms with social-capital-decreasing relocations. All variables in the analysis are based on data in the year immediately prior to the relocation event.

Panel A. Difference-in-Differences Regression Results

\begin{tabular}{|c|c|c|}
\hline \multirow[b]{2}{*}{ Variables } & \multicolumn{2}{|c|}{ Dependent Variable: In $\left(\mathrm{SPREAD}_{t}\right)$} \\
\hline & 1 & 2 \\
\hline POST & $\begin{array}{c}0.040 \\
(1.01)\end{array}$ & $\begin{array}{c}0.033 \\
(0.65)\end{array}$ \\
\hline SOCIAL_CAPITAL_INCREASING_RELOCATION & $\begin{array}{c}0.068 \\
(1.39)\end{array}$ & $\begin{array}{c}0.060 \\
(1.04)\end{array}$ \\
\hline POST × SOCIAL_CAPITAL_INCREASING_RELOCATION & $\begin{array}{l}-0.128^{\star \star} \\
(-2.54)\end{array}$ & $\begin{array}{l}-0.125^{*} \\
(-1.80)\end{array}$ \\
\hline $\ln \left(\right.$ ASSETS $\left._{t-1}\right)$ & 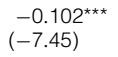 & $\begin{array}{l}-0.137^{\text {***}} \\
(-7.04)\end{array}$ \\
\hline PROFITABILITY $_{t-1}$ & $\begin{array}{l}-0.429^{\star \star \star} \\
(-3.67)\end{array}$ & $\begin{array}{l}-0.225 \\
(-1.37)\end{array}$ \\
\hline $\mathrm{MB}_{t-1}$ & $\begin{array}{l}-0.002 \\
(-0.68)\end{array}$ & $\begin{array}{l}-0.012^{\star \star} \\
(-2.27)\end{array}$ \\
\hline LEVERAGE $_{t-1}$ & $\begin{array}{l}0.532^{\star \star \star} \\
(8.16)\end{array}$ & $\begin{array}{l}0.461^{\star * *} \\
(5.18)\end{array}$ \\
\hline TANGIBILITY $_{t-1}$ & $\begin{array}{l}-0.369^{\star \star \star} \\
(-4.22)\end{array}$ & $\begin{array}{l}-0.215^{\star} \\
(-1.73)\end{array}$ \\
\hline $\operatorname{ZSCORE}_{t-1}$ & $\begin{array}{c}0.008 \\
(0.76)\end{array}$ & $\begin{array}{c}0.010 \\
(0.68)\end{array}$ \\
\hline CASH_HOLDING ${ }_{t-1}$ & $\begin{array}{c}0.130 \\
(0.85)\end{array}$ & $\begin{array}{l}0.541^{* * *} \\
(2.60)\end{array}$ \\
\hline EARNINGS_VOLATILITY ${ }_{t-1}$ & $\begin{array}{l}0.090^{\star \star \star} \\
(4.12)\end{array}$ & $\begin{array}{l}0.075^{\star \star} \\
(2.44)\end{array}$ \\
\hline SALES_GROWTH $H_{t-1}$ & $\begin{array}{c}0.035 \\
(1.48)\end{array}$ & $\begin{array}{l}0.068^{* *} \\
(2.06)\end{array}$ \\
\hline In(LOAN_SIZE $\left.{ }_{t}\right)$ & $\begin{array}{l}-0.107^{\star \star \star} \\
(-7.86)\end{array}$ & $\begin{array}{l}-0.108^{\text {*** }} \\
(-5.60)\end{array}$ \\
\hline $\operatorname{In}\left(\right.$ MATURITY $\left._{t}\right)$ & $\begin{array}{l}-0.046^{\star} \\
(-1.73)\end{array}$ & $\begin{array}{l}-0.030 \\
(-0.71)\end{array}$ \\
\hline DUMMY_SYNDICATION ${ }_{t}$ & $\begin{array}{l}-0.045 \\
(-1.06)\end{array}$ & $\begin{array}{l}-0.012 \\
(-0.17)\end{array}$ \\
\hline DEBT_RATING ${ }_{t}$ & $\begin{array}{l}0.090^{\star \star \star} \\
(6.03)\end{array}$ & $\begin{array}{l}0.055^{\star \star} \\
(2.51)\end{array}$ \\
\hline $\begin{array}{l}\text { County demographic factors } \\
\text { State, industry, loan-purpose, and loan-type effects }\end{array}$ & $\begin{array}{l}\text { Yes } \\
\text { Yes }\end{array}$ & $\begin{array}{l}\text { Yes } \\
\text { Yes }\end{array}$ \\
\hline $\begin{array}{l}\text { No. of obs. } \\
\text { Adj. } R^{2}\end{array}$ & $\begin{array}{l}1,778 \\
0.714\end{array}$ & $\begin{array}{r}952 \\
0.724\end{array}$ \\
\hline
\end{tabular}


TABLE 5 (continued)

Evidence from a Quasi-Experiment:

Firms with Social-Capital-Changing Headquarters Relocations

\begin{tabular}{|c|c|c|c|}
\hline \multirow[b]{2}{*}{ Variables } & \multicolumn{2}{|c|}{ Mean (Std. Dev.) } & \multirow[b]{2}{*}{$t$-Stat. } \\
\hline & $\begin{array}{c}\text { Sample of Firms with a } \\
\text { Social-Capital-Decreasing } \\
\text { Relocation } \\
\end{array}$ & $\begin{array}{c}\text { Sample of Firms with a } \\
\text { Social-Capital-Increasing } \\
\text { Relocation } \\
\end{array}$ & \\
\hline SPREAD & $173(151)$ & $168(145)$ & 0.23 \\
\hline In(ASSETS) & $6.968(2.16)$ & $6.689(1.83)$ & 0.82 \\
\hline PROFITABILITY & $0.007(0.137)$ & $0.014(0.151)$ & -0.92 \\
\hline MB & $2.44(2.18)$ & $2.13(1.84)$ & 0.93 \\
\hline LEVERAGE & $0.366(0.18)$ & $0.392(0.17)$ & -1.37 \\
\hline TANGIBILITY & $0.366(0.25)$ & $0.347(0.27)$ & 0.40 \\
\hline ZSCORE & $0.952(2.07)$ & $1.027(1.75)$ & -0.21 \\
\hline CASH_HOLDING & $0.066(0.13)$ & $0.072(0.14)$ & -0.29 \\
\hline EARNINGS_VOLATILITY & $0.715(0.70)$ & $0.643(0.57)$ & 1.08 \\
\hline SALES_GRŌWTH & $0.307(0.64)$ & $0.219(0.65)$ & 1.06 \\
\hline
\end{tabular}

\section{B. Evidence from Instrumental-Variable 2-Stage Regressions}

Following Barton and Waymire (2004) and Kim and Lu (2011), we use an instrumental-variable 2-stage regression as the second identification strategy to address a potential concern that our estimation in the baseline model is affected by the endogeneity of social capital due to omitted variables that are correlated with social capital and bank loan cost.

Putnam ((2001), p. 48) argues that "the best single predictor of the level of social capital in American states is distance to the Canadian border. Being closer to the Canadian border means more social capital." Therefore, we use $\ln$ (BORDER_DISTANCE) as the first instrument. $\ln$ (BORDER_DISTANCE) is the natural logarithm of the closest distance between the U.S.-Canadian border and the county in which a firm's headquarters is located. We expect that $\ln$ (BORDER_DISTANCE) is negatively correlated with social capital. Additionally, Putnam ((2007), p. 149) argues that "people living in ethnically diverse settings appear to 'hunker down' - that is, to pull in like a turtle." He provides evidence that ethnic homogeneity increases social solidarity and social capital. Accordingly, we use ETHNICITY_HOMOGENEITY as the second instrument. ETHNICITY_HOMOGENEITY is a Herfindahl index calculated across the Census Bureau ethnic categories of Hispanic, non-Hispanic black, non-Hispanic white, and Asian for a county in a given year. We expect that ETHNICITY_ HOMOGENEITY is positively correlated with social capital.

Model 1 of Table 6 presents results from the first-stage regression. The dependent variable is SOCIAL_CAPITAL, and the independent variables include the two instrumental variables and all control variables as specified in the baseline model. Coefficients on both instrumental variables are statistically significant. In particular, consistent with expectations, the estimate on $\ln$ (BORDER_DISTANCE) is negative, and the estimate on ETHNICITY HOMOGENEITY is positive. A valid instrumental variable in this setting should also have no direct effect on loan spread. We examine this condition and find that it is met. We include the instruments as additional control variables in the baseline 
TABLE 6

Instrumental-Variable 2-Stage Regressions

The sample consists of 18,313 firm-year observations during the period 1990-2012. Model 1 of Table 6 presents the

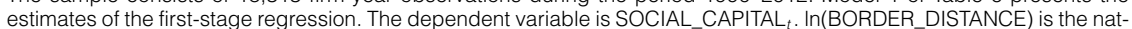
ural logarithm of the closest distance between a county and the U.S.-Canadian border. ETHNICITY_HOMOGENEITY is a Herfindahl index calculated across the Census Bureau ethnic categories of Hispanic, non-Hispanic black, nonHispanic white, and Asian in a county during a year. Table 1 provides definitions for the control variables. Model 2 presents the results of the second-stage regression. The dependent variable is $\ln \left(\operatorname{SPREAD}_{t}\right)$, which is the natural logarithm of the all-in loan spread drawn in basis points for a loan a firm obtains in year $t$, and we use the same control variables as specified in the baseline model of equation (1) to isolate the effects of firm, loan, and county demographic attributes; industry, state, and year effects; and loan purposes and types. Table 1 provides definitions for these variables. FITTED_SOCIAL_CAPITAL $t-1$ is the predicted value of social capital based on the first-stage regression. Standard errors are adjusted for heteroskedasticity and within-firm clustering. * , ${ }^{\star *}$, and ${ }^{* \star *}$ indicate significance at the $10 \%, 5 \%$, and $1 \%$ levels, respectively.

\begin{tabular}{|c|c|c|}
\hline \multirow{3}{*}{ Variables } & \multicolumn{2}{|c|}{ Dependent Variables } \\
\hline & \multirow{2}{*}{$\begin{array}{c}\text { SOCIAL_CAPITAL }_{t} \\
1\end{array}$} & \multirow{2}{*}{$\begin{array}{c}\ln \left(\mathrm{SPREAD}_{t}\right) \\
2\end{array}$} \\
\hline & & \\
\hline In(BORDER_DISTANCE $\left.{ }_{t}\right)$ & $\begin{array}{l}-0.102^{\star \star \star} \\
(-15.45)\end{array}$ & \\
\hline ETHNICITY_HOMOGENEITY $t_{t}$ & $\begin{array}{l}0.257^{\star \star \star} \\
(6.30)\end{array}$ & \\
\hline FITTED_SOCIAL_CAPITAL ${ }_{t-1}$ & & $\begin{array}{l}-0.200^{* *} \\
(-2.43)\end{array}$ \\
\hline $\ln \left(\right.$ ASSETS $\left._{t-1}\right)$ & $\begin{array}{l}-0.006 \\
(-1.32)\end{array}$ & $\begin{array}{l}-0.112^{\star \star \star} \\
(-17.44)\end{array}$ \\
\hline PROFITABILITY $_{t-1}$ & $\begin{array}{l}-0.022 \\
(-0.80)\end{array}$ & $\begin{array}{l}-0.294^{\star \star *} \\
(-9.96)\end{array}$ \\
\hline $\mathrm{MB}_{t-1}$ & $\begin{array}{l}-0.000 \\
(-0.05)\end{array}$ & $\begin{array}{l}-0.007^{* * *} \\
(-4.61)\end{array}$ \\
\hline LEVERAGE $_{t-1}$ & $\begin{array}{l}-0.045^{\star \star} \\
(-2.21)\end{array}$ & $\begin{array}{l}0.490^{\star \star \star} \\
(14.79)\end{array}$ \\
\hline TANGIBILITY $_{t-1}$ & $\begin{array}{l}0.082^{\star \star \star} \\
(3.08)\end{array}$ & $\begin{array}{l}-0.158^{\star \star \star} \\
(-4.10)\end{array}$ \\
\hline ZSCORE $_{t-1}$ & $\begin{array}{l}0.006^{\star} \\
(1.85)\end{array}$ & $\begin{array}{l}-0.021^{* \star *} \\
(-5.66)\end{array}$ \\
\hline $\mathrm{CASH}_{-} \mathrm{HOLDING} \mathrm{I}_{t-1}$ & $\begin{array}{l}-0.117^{\star \star \star} \\
(-3.28)\end{array}$ & $\begin{array}{c}0.003 \\
(0.07)\end{array}$ \\
\hline EARNINGS_VOLATILITY ${ }_{t-1}$ & $\begin{array}{l}-0.006 \\
(-0.93)\end{array}$ & $\begin{array}{l}0.108^{\star \star \star} \\
(12.01)\end{array}$ \\
\hline SALES_GROWTH $_{t-1}$ & $\begin{array}{l}-0.008 \\
(-0.92)\end{array}$ & $\begin{array}{l}0.033^{* \star \star} \\
(3.77)\end{array}$ \\
\hline In(LOAN_SIZE $\left.{ }_{t}\right)$ & $\begin{array}{c}0.003 \\
(0.73)\end{array}$ & $\begin{array}{l}-0.100^{\star \star \star} \\
(-15.89)\end{array}$ \\
\hline $\operatorname{In}\left(\right.$ MATURITY $\left._{t}\right)$ & $\begin{array}{l}-0.005 \\
(-0.88)\end{array}$ & $\begin{array}{l}-0.088^{\star \star \star} \\
(-7.43)\end{array}$ \\
\hline DUMMY_SYNDICATION ${ }_{t}$ & $\begin{array}{l}-0.008 \\
(-0.57)\end{array}$ & $\begin{array}{l}-0.072^{\star \star \star} \\
(-4.53)\end{array}$ \\
\hline DEBT_RATING ${ }_{t}$ & $\begin{array}{l}-0.020^{\star \star \star} \\
(-4.93)\end{array}$ & $\begin{array}{l}0.109^{\star \star \star} \\
(16.11)\end{array}$ \\
\hline $\ln \left(\operatorname{INCOME}_{t-1}\right)$ & $\begin{array}{l}-0.038 \\
(-1.03)\end{array}$ & $\begin{array}{l}-0.061 \\
(-1.20)\end{array}$ \\
\hline $\ln \left(\right.$ POPULATION $\left._{t-1}\right)$ & $\begin{array}{l}-0.231^{\star \star \star} \\
(-45.85)\end{array}$ & $\begin{array}{l}-0.048^{* *} \\
(-2.28)\end{array}$ \\
\hline $\ln \left(\mathrm{EDUCATION}_{t-1}\right)$ & $\begin{array}{l}0.982^{\star \star \star} \\
(35.51)\end{array}$ & $\begin{array}{l}0.252^{\star \star \star} \\
(2.73)\end{array}$ \\
\hline $\ln \left(\mathrm{AGE}_{t-1}\right)$ & $\begin{array}{l}2.456^{\star \star \star} \\
(26.74)\end{array}$ & $\begin{array}{l}0.719^{\star \star \star} \\
(2.75)\end{array}$ \\
\hline State, industry, year, loan-purpose, and loan-type effects & Yes & Yes \\
\hline $\begin{array}{l}\text { No. of obs. } \\
\text { Adj. } R^{2}\end{array}$ & $\begin{array}{r}18,313 \\
0.616\end{array}$ & $\begin{array}{r}18,313 \\
0.625\end{array}$ \\
\hline
\end{tabular}

model and find that they are uncorrelated with loan spread. Results from this additional analysis are not tabulated. 
Model 2 of Table 6 reports the results from the second-stage regression, in which we modify the baseline model by using FITTED_SOCIAL_CAPITAL in place of the original SOCIAL_CAPITAL variable. FITTED_SOCIAL_CAPITAL is the predicted value of the social capital variable based on the estimates obtained from the first-stage regression. We find that FITTED_SOCIAL_CAPITAL is negative and significant, indicating that the endogeneity of social capital is unlikely to be a serious issue affecting the estimation of the baseline model.

\section{Evidence from Nonprice Loan Terms, Public Bond Yields, and Choice of Debt Financing}

\section{A. Effects of Social Capital on Loan Collateral and Covenant Requirements}

Hypothesis 2 predicts that firms located in higher-social-capital areas incur less stringent nonprice loan terms when obtaining bank loans. We test this hypothesis by examining how social capital affects the use of a collateral requirement or the presence of at least one covenant requirement in a loan facility.

We use a dummy variable, DUMMY_COLLATERAL, to capture whether a loan facility has a collateral requirement. DUMMY_COLLATERAL equals 1 if a loan facility has a collateral requirement, and 0 otherwise. We continue to use the baseline model after replacing the dependent variable, $\ln$ (SPREAD), with DUMMY_COLLATERAL. We estimate the model using logistic regression, which predicts the likelihood that a loan facility stipulates a collateral requirement. Model 1 of Table 7 presents the results. The coefficient on SOCIAL_ CAPITAL is negative and significant. We assess the economic significance by computing the effect of a 1-standard-deviation increase in social capital on the probability of a loan's being secured, holding other variables at their means. We find that such an increase reduces the likelihood of a loan's being secured by $1.7 \%$. By way of comparison, Graham et al. (2008) report a corresponding increase of 8.6\% after a firm restates its financial statement, and Francis et al. (2012) report that a 1-standard-deviation increase in board independence reduces the likelihood of a loan's being secured by $3.2 \%$.

As do Graham et al. (2008), we set DUMMY_COLLATERAL to 0 when DealScan reports a missing value for the collateral requirement for a given loan facility. To ensure that our findings are not driven by this data-coding procedure, we estimate the model again after removing all loan-year observations with missing collateral data in DealScan. This results in a sample of roughly 22,000 observations. We find that the coefficient on SOCIAL_CAPITAL remains negative and significant. Results from this additional analysis are not tabulated.

We create a dummy variable, DUMMY_COVENANT, to capture whether a loan facility has at least one covenant restriction in place. Specifically, following Ivashina (2009) and Demerjian (2011), we set DUMMY_COVENANT to 1 when DealScan reports at least one covenant requirement for a given loan facility, and 0 otherwise. We run a logistic regression to estimate a modified specification of the baseline model that uses DUMMY_COVENANT as the dependent variable. Model 2 of Table 7 presents the results. The coefficient on SOCIAL_CAPITAL 


\section{Social Capital and Nonprice Loan Terms}

The sample contains 32,425 loan-year observations during the period 1990-2012. In all models of Table 7, the specification of the baseline model is used to estimate the effect of social capital on nonprice loan terms. The dependent variable in each model captures either collateral or covenant requirements in a loan facility. Models 1 and 2 report the logistic regression results with DUMMY COLLATERAL $t$ and DUMMY COVENANT ${ }_{t}$ as the dependent variable, respectively. DUMMY_COLLATERAL ${ }_{t}$ equals $\overline{1}$ if the loan facility a firm obtains in year $t$ has a collateral requirement, and 0 otherwise. DUMMY_COVENANT $t$ equals 1 if the loan facility a firm obtains in year $t$ has at least one covenant requirement, and 0 otherwise. Model 3 reports the results from OLS regression based on overall covenant intensity using a reduced sample of loan facilities with at least one covenant restriction as reported in DealScan. COVENANT_INTENSITY $t$ is the natural logarithm of 1 plus the total number of covenants in a loan facility a firm obtains in a year. Table 1 provides definitions for other variables. Standard errors are adjusted for heteroskedasticity and within-firm clustering. $z$-statistics or $t$-statistics are reported in parentheses. * ${ }^{* *}$, and ${ }^{* * *}$ indicate significance at the $10 \%, 5 \%$, and $1 \%$ levels, respectively.

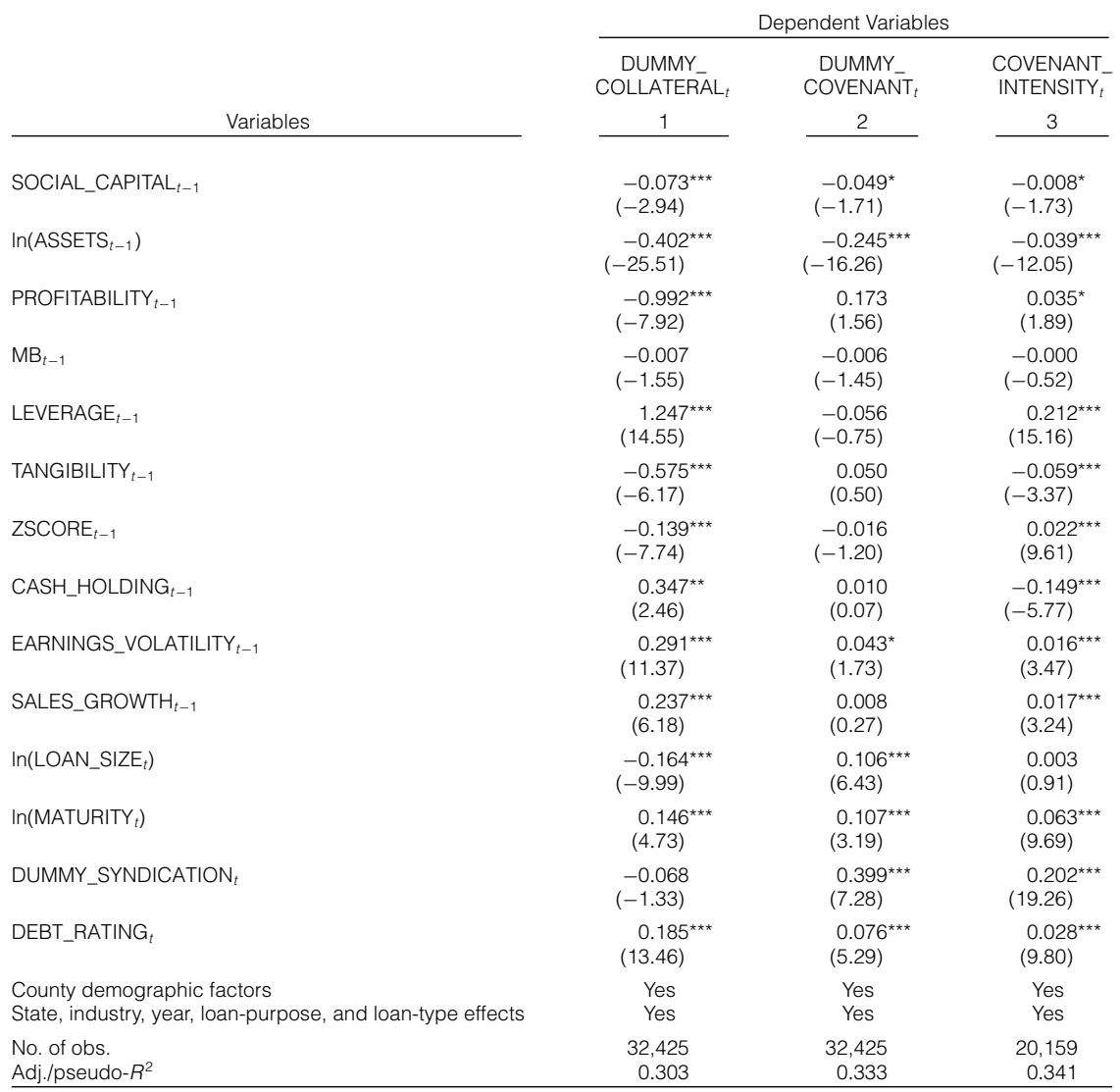

is negative and significant. We assess the economic significance of the result by computing the effect of a 1-standard-deviation increase in social capital on the probability of a loan's having at least one covenant in place, holding other variables at their means. We find that such an increase reduces the likelihood that banks impose at least one covenant by approximately $1.02 \%$. By way of comparison, Francis et al. (2012) find that a 1-standard-deviation increase in board independence reduces the likelihood that banks impose at least one covenant by approximately $1.95 \%$. 
We also estimate the effect of social capital on the intensity of covenant requirements using a reduced sample that includes only loan facilities for which DealScan reports at least one covenant restriction. This analysis is motivated by evidence in prior studies indicating a potential miscoding problem in covenant data in DealScan (e.g., Nini, Smith, and Sufi (2009)). Specifically, some loans coded as having missing data or no covenant restrictions may actually contain covenant restrictions. Following Graham et al. (2008), we define COVENANT_INTENSITY as the natural logarithm of 1 plus the total number of covenants in a loan facility. We use COVENANT_INTENSITY in place of the $\ln$ (SPREAD) and estimate the baseline model again. We report the results in model 3 of Table 7. We find that the coefficient on SOCIAL_CAPITAL remains negative and significant.

Taken together, these results indicate that banks impose less stringent nonprice loan terms when lending to firms located in counties with higher levels of social capital, providing support for Hypothesis 2. Together with the results on loan spreads, the evidence paints a fairly comprehensive and consistent picture suggesting that banks perceive social capital as constraining opportunistic firm behaviors in debt contracting; consequently, banks reduce loan spreads and relax collateral and covenant requirements when lending to firms located in counties with higher levels of social capital.

\section{B. Effect of Social Capital on Public Bond Yields}

Hypothesis 3 predicts that firms located in higher-social-capital areas incur lower at-issue bond spreads when issuing public bonds. We use a comprehensive sample of public bonds issued over the period 1990-2012 from the Securities Data Corporation (SDC) New Issues database to test this hypothesis. After merging the requisite bond data with our social capital data set, we obtain a sample of roughly 3,000 public bonds issued during the sample period. We modify the baseline model before estimating it again using OLS. We use $\ln$ (BOND_SPREAD) as the dependent variable. $\ln ($ BOND_SPREAD) is the natural logarithm of the difference between the yield to maturity on a coupon-paying corporate bond a firm issues in a year and the yield to maturity on a coupon-paying government bond with the same maturity date in that same year. We continue to use the baseline model after replacing the dependent variable with $\ln ($ BOND_SPREAD) and the loan-level control variables with five variables that capture attributes of the bonds. ${ }^{11}$

Model 1 of Table 8 reports the results. The coefficient on SOCIAL_ CAPITAL is negative and significant; more importantly, it is more than double the corresponding coefficient of model 4 in Table 3. Based on this estimate, a 1-standard-deviation increase in SOCIAL_CAPITAL in the data reduces at-issue bond yields by approximately 7.98 bps; by way of comparison, the estimate in

\footnotetext{
${ }^{11} \ln$ (BOND_SIZE) is the natural logarithm of issue proceeds of a bond. $\ln$ (BOND_MATURITY) is the natural logarithm of a bond's months to maturity. DUMMY_CALLABLE is an indicator variable equal to 1 if a bond is a callable bond, and 0 otherwise. DUMMY_PRIVATE is an indicator variable equal to 1 if a bond is issued through a private placement, and 0 otherwise. DUMMY_SENIOR is an indicator variable equal to 1 if a bond is a senior bond, and 0 otherwise. We also include dummy variables to control for bond rating, state, year, and industry effects.
} 


\section{TABLE 8}

\section{Effects of Social Capital on Public Bond Yields and Firms' Debt-Financing Choices}

The dependent variable in model 1 of Table 8 is In(BOND_SPREAD $)_{t}$, which is the natural logarithm of the difference between the yield to maturity on a coupon-paying corporate bond that a firm issues in year $t$ and the yield to maturity on a coupon-paying government bond with the same maturity date. The sample consists of 2,937 bond-year observations for the period 1990-2012. The model is estimated using OLS regression. As in the baseline model, the test variable is SOCIAL_CAPITAL $t_{-1}$, and controls include firm-level attributes, county demographic attributes, debt rating, and year, state, and industry dummies. Table 1 provides definitions for these variables. In $\left(\mathrm{BOND}_{-} \mathrm{SIZE}_{t}\right)$ is the natural logarithm of the issue proceeds of a bond. In(BOND MATURITY $)$ is the natural logarithm of a bond's months to maturity. DUMMY_CALLABLE $E_{t}$ equals 1 if a bond is callable, and 0 otherwise. DUMMY PRIVATE $E_{t}$ equals 1 if a bond is issued through a private placement, and 0 otherwise. DUMMY_SENIOR $t$ equals 1 if a bond is a senior bond, and 0 otherwise. In model 2, the dependent variable is DUMMY LOAN ${ }_{t}$, which equals 1 if a firm accesses debt from the bank loan market in a given year, and 0 if a firm obtains debt financing from the bond market. The sample contains 17,929 firm-year observations, and a logistic regression is used to estimate the model, with dummy variables included in the model to control for state, industry, and year effects. DISCRETIONARY ACCRUAL, is computed using the modified cross-sectional Jones (1991) model, as described by Dechow et al. (1995). STOCK_MARKET_ACCESS $t$ equals 1 if a firm obtains financing from the equity market in year $t$, and 0 otherwise. In both models, standard errors are adjusted for heteroskedasticity and within-firm clustering. $z$-statistics or $t$-statistics are reported in parentheses. ${ }^{*}$, ${ }^{* *}$, and ${ }^{* \star *}$ indicate significance at the $10 \%, 5 \%$, and $1 \%$ levels, respectively.

\begin{tabular}{|c|c|c|}
\hline \multirow[b]{3}{*}{ Variables } & \multicolumn{2}{|c|}{ Dependent Variables } \\
\hline & 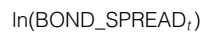 & DUMMY_LOAN \\
\hline & 1 & 2 \\
\hline SOCIAL_CAPITAL $_{t-1}$ & $\begin{array}{l}-0.078^{\star \star \star} \\
(-2.69)\end{array}$ & $\begin{array}{l}-0.062^{*} \\
(-1.93)\end{array}$ \\
\hline $\ln \left(\right.$ ASSETS $\left._{t-1}\right)$ & $\begin{array}{l}-0.192^{\star \star \star} \\
(-13.37)\end{array}$ & $\begin{array}{l}-0.530^{\star \star *} \\
(-33.58)\end{array}$ \\
\hline $\mathrm{MB}_{t-1}$ & $\begin{array}{l}-0.011^{\star \star \star} \\
(-2.74)\end{array}$ & $\begin{array}{l}-0.811^{\star \star \star} \\
(-7.43)\end{array}$ \\
\hline LEVERAGE $_{t-1}$ & $\begin{array}{l}0.377^{\star \star \star} \\
(3.13)\end{array}$ & $\begin{array}{l}-0.237^{\star \star \star} \\
(-3.67)\end{array}$ \\
\hline TANGIBILITY $_{t-1}$ & $\begin{array}{c}0.019 \\
(0.29)\end{array}$ & $\begin{array}{l}-0.021^{\star \star \star} \\
(-2.87)\end{array}$ \\
\hline ZSCORE $_{t-1}$ & $\begin{array}{l}-0.089^{\star \star \star} \\
(-4.13)\end{array}$ & $\begin{array}{l}0.066^{\star *} \\
(1.98)\end{array}$ \\
\hline DISCRETIONARY_ACCRUAL $L_{t-1}$ & & $\begin{array}{l}-0.405 \\
(-1.37)\end{array}$ \\
\hline STOCK_MARKET_ACCESS ${ }_{t-1}$ & & $\begin{array}{l}-1.485^{\star \star \star} \\
(-3.66)\end{array}$ \\
\hline PROFITABILITY $_{t-1}$ & $\begin{array}{l}-1.998^{\star \star \star} \\
(-6.41)\end{array}$ & \\
\hline CASH_HOLDING ${ }_{t-1}$ & $\begin{array}{l}1.115^{\star \star *} \\
(4.34)\end{array}$ & \\
\hline EARNINGS_VOLATILITY & $\begin{array}{l}0.054^{\star *} \\
(2.23)\end{array}$ & \\
\hline SALES_GROWTH $H_{t-1}$ & $\begin{array}{l}0.139^{\star \star \star} \\
(2.98)\end{array}$ & \\
\hline $\operatorname{In}\left(\mathrm{BOND} \_\mathrm{SIZE} t\right)$ & $\begin{array}{l}0.050^{\star \star \star} \\
(4.79)\end{array}$ & \\
\hline $\ln \left(B O N D \_M A T U R I T Y_{t}\right)$ & $\begin{array}{l}0.238^{\star \star \star} \\
(10.74)\end{array}$ & \\
\hline DUMMY_CALLABLE ${ }_{t}$ & $\begin{array}{r}0.386 \\
(1.22)\end{array}$ & \\
\hline DUMMY_PRIVATE ${ }_{t}$ & $\begin{array}{l}-0.048 \\
(-0.31)\end{array}$ & \\
\hline DUMMY_SENIOR ${ }_{t}$ & $\begin{array}{l}-0.482^{\star \star \star} \\
(-7.92)\end{array}$ & \\
\hline $\begin{array}{l}\text { Debt rating and county demographic factors } \\
\text { State, industry, and year effects }\end{array}$ & $\begin{array}{l}\text { Yes } \\
\text { Yes }\end{array}$ & $\begin{array}{l}\text { No } \\
\text { Yes }\end{array}$ \\
\hline $\begin{array}{l}\text { No. of obs. } \\
\text { Adj./pseudo- } R^{2}\end{array}$ & $\begin{array}{l}2,937 \\
0.564\end{array}$ & $\begin{array}{r}17,929 \\
0.163\end{array}$ \\
\hline
\end{tabular}


model 4 in Table 3 indicates that an analogous increase in SOCIAL_CAPITAL reduces bank loan spreads by approximately 4.33 bps. The finding that social capital has a greater incremental effect on bond yields than on bank loan spreads is consistent with Bharath et al. (2008) and Hasan et al. (2014), who find that bond investors are significantly more sensitive than banks in pricing risks into interest spreads. More importantly, they corroborate the argument that public bond holders perceive social capital as providing environmental pressure constraining opportunistic firm behaviors in debt contracting; consequently, they impose lower at-issue bond spreads when lending to firms with headquarters located in counties with higher levels of social capital. ${ }^{12}$

\section{Effect of Social Capital on Choice of Debt Financing}

Hypothesis 4 predicts that firms located in higher-social-capital areas are less likely to obtain bank loans relative to issuing bonds when seeking debt financing. To examine this hypothesis, we adopt the empirical model of Bharath et al. (2008), which frames the problem of the firm's debt-financing decision as a choice between private bank debt and a public bond. Accordingly, the dependent variable, DUMMYLOAN, takes on the value of 1 if a firm accesses debt from the private bank loan market in a given year, and it equals 0 if a firm chooses to obtain debt financing from the public bond market. Following Bharath et al. (2008), we include controls to isolate the effects of firm size, profitability, growth potential, leverage, asset tangibility, discretionary accruals, and the firm's ability to obtain equity financing. We construct the testing sample by merging the bank loan sample and the public bond sample used in previous analyses. We remove the firm-year observation if a firm issued a bond and obtained a bank loan in the same year, resulting in a sample of almost 18,000 firm-year observations in which the firm either issued public bonds or borrowed bank loans in a specific year over the period 1990-2012.

We use logistic regression to predict the likelihood that firms obtain debt financing from the bank loan market rather than the public bond market in a given year. Model 2 of Table 8 presents the estimates. We find that larger firms, highly levered firms, firms with tangible assets, and firms with a greater ability to obtain equity financing are less likely to obtain debt financing from the bank loan market. These results are consistent with Bharath et al. (2008). The coefficient on SOCIAL_CAPITAL is negative and significant, suggesting that social capital has an incremental effect of reducing the likelihood that a firm chooses to obtain debt financing from the bank loan market rather than the public bond market. The finding is consistent with Hypothesis 4 that social capital reduces the firm's preference for bank loans over public bonds when seeking debt financing.

\footnotetext{
${ }^{12}$ Engelberg et al. (2012) find that personal relationships between lenders and borrowers affect loan spreads. It is plausible that a higher level of social capital is associated with more opportunities for interactions between executives of borrowing firms and bank executives. Consequently, the results based on loan spreads could be due to the relationship effect as portrayed by Engelberg et al. However, the personal relationships between dispersed bond investors and managers of borrowing firms are very likely infrequent, so the result for bond contracting is unlikely to be influenced by personal relationships and social networks between bond investors and borrowers (Engelberg et al.).
} 


\section{Conclusion}

This study introduces the social capital construct into the debt-contracting literature by exploring its effect on bank loan cost. We find that firms located in U.S. counties with higher levels of social capital incur significantly lower loan spreads when obtaining debt financing from banks. We identify the causal effect of social capital on bank loan cost via a quasi-experiment that utilizes companies with a social-capital-changing relocation. Through a range of sensitivity analyses, we establish that the effect of social capital on bank loan spread is robust. Additionally, we find that banks demand less stringent collateral and covenant requirements when lending to firms headquartered in counties with higher levels of social capital, investors of public bonds demand significantly lower at-issue yield spreads when lending to firms with headquarters in counties with higher levels of social capital, and firms headquartered in counties with higher levels of social capital prefer bonds over loans when seeking debt financing.

Taken together, these results provide direct evidence that debt holders, including private banks and public bond investors, perceive social capital as providing environmental pressure that constrains opportunistic firm behaviors in debt contracting; consequently, they reduce the cost of debt when extending credit to firms with headquarters located in U.S. counties with higher levels of social capital. Guiso et al. (2010) contend that social capital can engender positive economic payoffs. To the extent that debt capital is a dominant funding source for U.S. corporations (Bharath et al. (2008)), our results suggest that social capital produces significant benefits for public corporations by reducing their cost of debt capital.

More broadly, our results contribute to an emerging stream of literature that examines nonreligious social influences on economic behaviors. Among these studies, there is strong evidence that social influences affect the decisions made by individuals. For example, Hong, Kubik, and Stein (2004) find that the frequency of a person's social interactions enhances his or her participation in the stock market. Pevzner, Xie, and Xin (2015) find that residents in societies with higher levels of trustworthiness perceive corporate earnings information as more credible. To date, few studies have examined the effect of social influences on publicly listed corporations. A notable exception is the work of Jha and Chen (2015), which examines the effect of social influences on audit pricing. Their argument is that norms and networks in a social environment affect the trustworthiness of the environment, which, in turn, affects audit pricing. We go beyond these authors to pin down the effect of a specific class of social norms, namely, cooperative norms, and focus on how these norms together with dense social networks affect opportunistic firm behaviors in debt contracting. In any case, we view the findings in both of these studies as initial evidence contributing to an understanding of how social environments affect corporations. A fruitful course of future research is to explore the effects of social influences on corporate policies and activities.

\section{Appendix. Constructing the Social Capital Measure}

This Appendix describes the procedure and the variables involved in constructing the SOCIAL_CAPITAL variable. The following sections list the variables provided by the NRCRD at Pennsylvania State University. The NRCRD reports the variables and their data 
in two different data sets. The old data set, OLD_NRCRD, reports data for 1990, 1997, and 2005. The new data set, NEW_NRCRD, reports data for 1997, 2005, and 2009. All of the variables listed in Section A-1, except NCCS and ASSN, are based on the corresponding 1990 data from the OLD_NRCRD and the 1997, 2005, and 2009 data from the NEW_NRCRD. Following Rupasingha et al. (2006), SOCIAL_CAPITAL is the first principal component from a PCA based on PVOTE, RESPN, NCCS, and ASSN. The SOCIAL_CAPITAL variable is estimated in 1990, 1997, 2005, and 2009. Data for missing years are back-filled using estimates in the preceding year for which data are available. For example, we fill in missing data for SOCIAL_CAPITAL from 1991 to 1996 using SOCIAL_CAPITAL estimates in 1990.

\section{Principal Factors}

PVOTE: Percentage of voters who voted in presidential elections.

RESPN: Response rate to the Census Bureau's decennial census.

NCCS: Sum of tax-exempt nonprofit organizations divided by populations per 10,000. We observe significant discrepancies in the reported NCCS values between OLD_NRCRD and NEW_NRCRD in 1997. There are two reasons for these discrepancies. First, OLD_NRCRD includes all nonprofit organizations, but NEW_NRCRD excludes nonprofits with an international reach. Second, OLD_NRCRD data might be incomplete, because they report many counties with very few nonprofit organizations in 1990. Accordingly, we use the 1997, 2005, and 2009 NCCS data from NEW_NRCRD and estimate the 1990 NCCS data as follows:

Estimated $1990 \mathrm{NCCS}=1997 \mathrm{NCCS} \div(1+$ average growth rate of NCCS between 1997 and 2005 and between 2005 and 2009),

where NCCS data from the left-hand side of the equation are based on data from NEW_NRCRD. We use this procedure because there is an upward trend in the number of nonprofit organizations from 1997 to 2009, as reported in NEW_NRCRD. The mean numbers of nonprofit organizations in NEW_NRCRD are 354, 443, and 495 for the years 1997, 2005, and 2009, respectively.

ASSN: Sum of social organizations divided by populations per 100,000 . We use the data for the 10 types of social organizations listed in Section A-2 to calculate the sum of social organizations because these are the organizations that are consistently reported in both OLD_NRCRD and NEW_NRCRD. OLD_NRCRD includes additional information for organizations, such as membership sports and recreation clubs, in 1990 and 1997, but NEW_NRCRD no longer carries the information for these organizations in 2005 and 2009. Accordingly, we use the 2005 and 2009 ASSN data from NEW_NRCRD and calculate the 1990 and 1997 ASSN using the 10 types of social organizations provided in OLD_NRCRD and NEW_NRCRD, respectively.

\section{Social Organizations}

RELIG: Number of religious organizations.

CIVIC: Number of civic and social associations.

BUS: Number of business associations.

POL: Number of political organizations.

PROF: Number of professional organizations.

LABOR: Number of labor organizations.

BOWL: Number of bowling centers. 
FITNS: Number of physical fitness facilities.

GOLF: Number of public golf courses.

SPORT: Number of sports clubs, managers, and promoters.

\section{References}

Alesina, A., and E. La Ferrara. "Participation in Heterogeneous Communities." Quarterly Journal of Economics, 115 (2000), 847-904.

Barton, J., and G. Waymire. "Investor Protection under Unregulated Financial Reporting." Journal of Accounting and Economics, 38 (2004), 65-116.

Bebchuk, L. "Ex Ante Costs of Violating Absolute Priority in Bankruptcy." Journal of Finance, 57 (2002), 445-460.

Besanko, D., and G. Kanatas. "Credit Market Equilibrium with Bank Monitoring and Moral Hazard." Review of Financial Studies, 6 (1993), 213-232.

Bharath, S. T.; S. Dahiya; A. Saunders; and A. Srinivasan. "Lending Relationships and Loan Contract Terms." Review of Financial Studies, 24 (2011), 1141-1203.

Bharath, S.; J. Sunder; and S. Sunder. "Accounting Quality and Debt Contracting." Accounting Review, 83 (2008), 1-28.

Bjornskov, C. "Corruption and Social Capital." Working Paper, Aarhus School of Business (2003).

Buonanno, P.; D. Montolio; and P. Vanin. "Does Social Capital Reduce Crime?" Journal of Law and Economics, 52 (2009), 145-170.

Cai, J., and G. Shi. "Value of Faith: Evidence on Religious Environment and Cost of Debt." Working Paper, Drexel University (2014).

Coleman, J. "Social Capital in the Creation of Human Capital." American Journal of Sociology, 94 (1988), S95-S120.

Dechow, P.; R. Sloan; and A. Sweeney. "Detecting Earnings Management." Accounting Review, 70 (1995), 193-225.

DeFond, M., and J. Jiambalvo. "Debt Covenant Violation and Manipulation of Accruals." Journal of Accounting and Economics, 17 (1994), 145-176.

Demerjian, P. "Accounting Standards and Debt Covenants: Has the 'Balance Sheet Approach' Led to a Decline in the Use of Balance Sheet Covenants?" Journal of Accounting and Economics, 52 (2011), 178-202.

Denis, D., and V. Mihov. "The Choice among Bank Debt, Nonbank Private Debt, and Public Debt: Evidence from New Corporate Borrowings." Journal of Financial Economics, 70 (2003), 3-28.

Diamond, D. W. "Monitoring and Reputation: The Choice between Bank Loans and Directly Placed Debt." Journal of Political Economy, 99 (1991), 689-721.

Duarte, J.; S. Siegel; and L. Young. "Trust and Credit: The Role of Appearance in Peer-to-Peer Lending." Review of Financial Studies, 25 (2012), 2455-2484.

Elster, J. "Social Norms and Economic Theory." Journal of Economic Perspectives, 3 (1989), 99-117.

Engelberg, J.; P. Gao; and C. A. Parsons. "Friends with Money." Journal of Financial Economics, 103 (2012), 169-188.

Fama, E. “What's Different about Banks?” Journal of Monetary Economics, 15 (1985), 29-39.

Fischer, H., and T. Pollock. "Effects of Social Capital and Power on Surviving Transformational Change: The Case of Initial Public Offerings." Academy of Management Journal, 47 (2004), 463-481.

Francis, B.; I. Hasan; M. Koetter; and Q. Wu. “Corporate Boards and Bank Loan Contracting.” Journal of Financial Research, 35 (2012), 521-552.

Fukuyama, F. "Social Capital and the Global Economy." Foreign Affairs, 74 (1995), 89-104.

Fukuyama, F. "Social Capital and the Modern Capitalist Economy: Creating a High Trust Workplace." Stern Business Magazine, 4 (1997), 4-17.

Funk, P. "Social Incentives and Voter Turnout: Evidence from the Swiss Mail Ballot System.” Journal of the European Economic Association, 8 (2010), 1077-1103.

Galai, D., and R. Masulis. "The Option Pricing Model and the Risk Factor of Stock." Journal of Financial Economics, 3 (1976), 53-81.

Gompers, P.; J. Ishii; and A. Metrick. "Corporate Governance and Equity Prices." Quarterly Journal of Economics, 118 (2003), 107-155.

Goss, A., and G. Roberts. "The Impact of Corporate Social Responsibility on the Cost of Bank Loans." Journal of Banking and Finance, 35 (2011), 1794-1810.

Graham, J.; S. Li; and J. Qiu. "Corporate Misreporting and Bank Loan Contracting." Journal of Financial Economics, 89 (2008), 44-61. 
Guiso, L.; P. Sapienza; and L. Zingales. "The Role of Social Capital in Financial Development." American Economic Review, 94 (2004), 526-556.

Guiso, L.; P. Sapienza; and L. Zingales. "Civic Capital as the Missing Link.” In Handbook of Social Economics, J. Benhabib, A. Bisin, and M. Jackson, eds. Oxford, UK: Elsevier Science (2010), $417-480$.

Hasan, I.; C. K. Hoi; Q. Wu; and H. Zhang. "Beauty Is in the Eye of the Beholder: The Effect of Corporate Tax Avoidance on the Cost of Bank Loans.” Journal of Financial Economics, 113 (2014), $109-130$.

Hasan, I.; C. K. Hoi; Q. Wu; and H. Zhang. "Does Social Capital Affect Corporate Decisions? Evidence from Corporate Tax Avoidance." Journal of Accounting Research, forthcoming (2017).

Higgins, T. "Self-Discrepancy: A Theory Relating Self and Affect." Psychological Review, 94 (1987), 319-340.

Hilary, G., and K. W. Hui. "Does Religion Matter in Corporate Decision Making in America?" Journal of Financial Economics, 93 (2009), 455-473.

Hoi, C. K.; Q. Wu; and H. Zhang. "Community Social Capital and Corporate Social Responsibility." Journal of Business Ethics, forthcoming (2017).

Hong, H.; J. D. Kubik; and J. Stein. "Social Interaction and Stock-Market Participation." Journal of Finance, 59 (2004), 137-163.

Ivashina, V. "Asymmetric Information Effects on Loan Spreads.” Journal of Financial Economics, 92 (2009), 300-319.

Jha, A., and Y. Chen. "Audit Fees and Social Capital.” Accounting Review, 90 (2015), 611-639.

Jiang, F.; K. John; W. Li; and Y. Qian. "Earthly Reward to the Religious: Religiosity and the Costs of Public and Private Debt." Working Paper, University of Iowa (2014).

Jones, J. "Earnings Management during Import Relief Investigations." Journal of Accounting Research, 29 (1991), 193-228.

Kim, E. H., and Y. Lu. "CEO Ownership, External Governance, and Risk-Taking.” Journal of Financial Economics, 102 (2011), 272-292.

Klock, M. S.; S. Mansi; and W. Maxwell. "Does Corporate Governance Matter to Bondholders?" Journal of Financial and Quantitative Analysis, 40 (2005), 693-719.

Knack, S. "Social Capital and the Quality of Government: Evidence from the States." American Journal of Political Science, 46 (2002), 772-785.

Knack, S., and P. Keefer. "Does Social Capital Have an Economic Payoff? A Cross-Country Investigation." Quarterly Journal of Economics, 112 (1997), 1251-1288.

Krishnaswami, S.; P. A. Spindt; and V. Subramaniam. "Information Asymmetry, Monitoring, and the Placement Structure of Corporate Debt." Journal of Financial Economics, 51 (1999), 407-434.

La Porta, R.; F. Lopez-de-Silanes; A. Shleifer; and R. Vishny. "Trust in Large Organizations." American Economic Review, 87 (1997), 333-338.

Lederman, D.; N. Loayza; and A. Menendez. "Violent Crime: Does Social Capital Matter?” Economic Development and Cultural Change, 50 (2002), 509-539.

Mazar, N.; O. Amir; and D. Ariely. "The Dishonesty of Honest People: A Theory of Self-Concept Maintenance." Journal of Marketing Research, 45 (2008), 633-644.

Monin, B., and A. Jordan. "The Dynamic Moral Self: A Social Psychological Perspective." In Explorations in Moral Psychology, D. Narvaez and D. Lapsley, eds. Cambridge, UK: Cambridge University Press (2009), 341-354.

Nakamura, L. "Commercial Bank Information: Information for the Structure of Banking." In Structural Change in Banking, L. White and M. Klausner, eds. Homewood, IL: Business One Irwin (1993), 131-160.

Nini, G.; D. C. Smith; and A. Sufi. "Creditor Control Rights and Firm Investment Policy.” Journal of Financial Economics, 92 (2009), 400-420.

Pevzner, M.; F. Xie; and X. Xin. "When Firms Talk, Do Investors Listen? The Role of Trust in Stock Market Reactions to Corporate Earnings Announcements." Journal of Financial Economics, 117 (2015), 190-223.

Posner, E. Law and Social Norms. Cambridge, MA: Harvard University Press (2000).

Posner, R. "A Theory of Primitive Society, with Special Reference to Law." Journal of Law and Economics, 23 (1980), 1-53.

Putnam, R. Making Democracy Work: Civic Traditions in Modern Italy. Princeton, NJ: Princeton University Press (1993).

Putnam, R. "Social Capital: Measurement and Consequences." Canadian Journal of Policy Research, 2 (2001), 41-51.

Putnam, R. "E Pluribus Unum: Diversity and Community in the Twenty-First Century. The 2006 Johan Skytte Prize Lecture.” Scandinavian Political Studies, 30 (2007), 137-174. 
Rupasingha, A., and S. Goetz. "Social and Political Forces as Determinants of Poverty." Journal of Socio-Economics, 36 (2007), 650-671.

Rupasingha, A.; S. Goetz; and D. Freshwater. "The Production of Social Capital in US Counties." Journal of Socio-Economics, 35 (2006), 83-101.

Spagnolo, G. "Social Relations and Cooperation in Organizations." Journal of Economic Behavior and Organization, 38 (1999), 1-25.

Strahan, P. E. "Borrower Risk and the Price and Nonprice Terms of Bank Loans." Federal Reserve Bank of New York Staff Report 90 (1999).

Uhlaner, C. "Rational Turnout: The Neglected Role of Groups." American Journal of Political Science, 33 (1989), 390-422.

Uzzi, B. "The Sources and Consequences of Embeddedness for the Economic Performance of Organizations: The Network Effect." American Sociological Review, 61 (1996), 674-698.

Valta, P. “Competition and the Cost of Debt." Journal of Financial Economics, 105 (2012), 661-682. 